\title{
Assessment of antibiotic susceptibility in Lactobacillus isolates from chickens
}

\author{
Marta Dec ${ }^{*} \mathbb{0}$, Renata Urban-Chmiel, Dagmara Stępień-Pyśniak and Andrzej Wernicki
}

\begin{abstract}
Background: The aim of this study was to determine the susceptibility of 88 Lactobacillus isolates derived from chickens to antibiotic substances and to detect drug-resistance genes.

Results: The minimal inhibitory concentration of 13 antimicrobial substances was determined by the broth microdilution method, and resistance genes were detected by PCR. We recorded a high prevalence of resistance to tiamulin (90\% resistant isolates), tetracyclines (74\%) and lincomycin (70\%), and a moderately high frequency of resistance to enrofloxacin (48\%), macrolides (42\%), aminoglycosides (12.5-31\%), ampicillin (26\%) and chloramphenicol (23\%). Multi-drug resistance was observed in $79.5 \%$ of isolates. The presence of resistance genes was generally correlated with phenotypic resistance, but some molecular determinants were also recorded in susceptible isolates. Among tetracycline resistance genes, the most frequently identified was tetW ( $45 \%$ isolates), followed by tetM (26\%) and tetL (24\%). The ermB, ermC and InuA genes, associated with resistance to macrolides and lincosamides, were observed in 39,12 and $39 \%$ of isolates, respectively. Among genes determining resistance to aminoglycoside antibiotics, we iden-

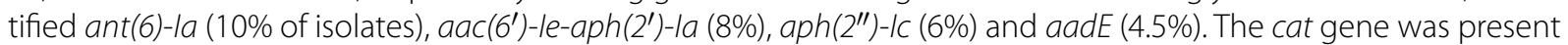
in 32 isolates, including 8 of 20 found to be resistant to chloramphenicol. Two genes encoding efflux pumps were identified - the acrA gene was present in all isolates tested, and 10 of 79 lactobacilli determined to be phenotypically resistant to tiamulin contained the IsaE gene. We were unable to explain the resistance mechanism of Lactobacillus isolates to ampicillin, but showed that it did not involve the production of $\beta$-lactamases.

Conclusions: Our findings indicate that intestinal lactobacilli should be considered a reservoir of resistance genes and that antibiotics must be used prudently in poultry production. The data derived from this study can be used as a basis for reviewing current microbiological breakpoints for categorization of susceptible and resistant strains within the genus Lactobacillus.
\end{abstract}

Keywords: Antibiotic susceptibility, Lactobacillus, Poultry, Resistance genes

\section{Background}

Lactobacilli are Gram-positive rod-shaped non-pathogenic bacteria considered to be beneficial components of the gastrointestinal microbiota of humans and animals, including birds. They play an important role in the physiology of their host, as they maintain the microbial balance around mucous membranes via ecological interactions with the resident flora and beneficially influence the immune system via the GALT. Moreover, they

\footnotetext{
*Correspondence: marta.dec@up.lublin.pl; martde16@gmail.com
} Sub-Department of Veterinary Prevention and Avian Diseases, Institute of Biological Bases of Animal Diseases, Faculty of Veterinary Medicine, University of Life Sciences in Lublin, Akademicka 12, 20-033 Lublin, Poland improve digestion and assimilation of nutrients and remove toxic substances [1]. Owing to their health-promoting properties, many Lactobacillus strains are used to produce probiotic preparations for humans and animals, and interest in applications for these bacteria continues to grow.

As modern intensive poultry farming and the associated high density of birds are conducive to the rapid spread of germs, the demand for veterinary drugs, including antibiotics, is high. However, antibiotics are becoming less effective due to bacterial resistance, and the hypothesis that the gastrointestinal tract (GIT) acts as a reservoir of antibiotic resistance genes is widely accepted [2]. High density of micro-organisms within this 
ecosystem facilitates the exchange of resistance genes among members of the microbiota, including both commensals and pathogens. Antibiotic-resistant strains not only pose a danger to animals, but as they spread via the food chain, also contribute to problems in humans.

The aim of this study was to determine the susceptibility of Lactobacillus strains derived from chickens to antibiotic substances and to detect drug-resistance genes. To the best of our knowledge, the current literature does not provide comprehensive studies on the antibiotic susceptibility of chicken lactobacilli. There are only two reliable reports $[3,4]$ of phenotypic and genotypic susceptibility of chicken lactobacilli to tetracycline and MLS antibiotics (macrolides, lincosamides and streptogramins).

Most of the antibiotics and chemotherapeutics tested are currently approved for treatment of poultry diseases in the EU. Tetracyclines, such as oxytetracycline, chlortetracycline, and doxycycline, are recommended for controlling mycoplasmosis and chlamydiosis in poultry, as well as against susceptible strains of various bacteria, including spirochetes, and some protozoa. Macrolides and lincosamides are common therapeutic agents for necrotic enteritis (Clostridium perfringens) and intestinal spirochetes (Brachyspira pilosicoli), while tylosin and tiamulin are important drugs in controlling chronic respiratory diseases caused by mycoplasmas [5]. Aminoglycosides are particularly effective against Gram-negative bacteria and are poorly absorbed from the gastrointestinal tract. Hence neomycin is commonly used against enteric infections (e.g., salmonellosis or colibacillosis) in poultry [5]. Penicillins, such as amoxicillin, are effective against susceptible strains of various Gram-positive and Gram-negative bacteria, especially in the treatment of $E$. coli septicaemia, salmonellosis, pasteurellosis, necrotic enteritis and chronic respiratory disease in poultry. Fluoroquinolones, including enrofloxacin, flumequine and difloxacin, are synthetic broad-spectrum bactericidal drugs that are frequently used in poultry production to treat salmonellosis, colibacillosis and fowl cholera [6].

The mechanism of action of tetracyclines, MLS antibiotics, aminoglycosides, pleuromutilins and chloramphenicol is based on inhibition of protein synthesis in bacterial cells. Tetracyclines bind to the $30 \mathrm{~S}$ subunit of ribosomes and prevent the attachment of tRNAs carrying amino acids. MLS antibiotics, tiamulin, and chloramphenicol bind to the $50 \mathrm{~S}$ ribosomal subunit and/or to peptidyl transferase-an enzyme responsible for forming peptide bonds between amino acids [7]. Beta-lactam antibiotics inhibit bacterial cell wall synthesis by interacting with penicillin binding proteins (PBPs) [5], while fluoroquinolones inhibit DNA replication by binding to the DNA gyrase [6].
The use of antibacterial agents creates selective pressure for the emergence of resistant strains, both pathogenic and commensal. Antibiotic resistance, which is implicated in elevated morbidity and mortality rates as well as increased treatment costs, is considered a major global public health threat (http://www.who.int/drugresistance/en/). Bacteria may be intrinsically resistant to antimicrobial agents or may acquire resistance by de novo mutation or via the acquisition of resistance genes from other organisms. Acquired resistance genes may enable a bacterium to produce enzymes that destroy the antibacterial drug, to express efflux systems that prevent the drug from reaching its intracellular target, to modify the drug's target site, or to produce an alternative metabolic pathway that bypasses the action of the drug. Many antibiotic resistance genes are carried on plasmids, transposons or integrons that can act as vectors that transfer these genes to other members of the same bacterial species, as well as to bacteria of other genera or species. Horizontal gene transfer may occur via three main mechanisms: transformation, transduction or conjugation [8].

Lactobacilli are commonly used as probiotics and according to the EFSA's FEEDAP Panel (European Food Safety Authority Panel on Additives and Products or Substances used in Animal Feed) all bacterial strains intended for use as feed additives must be examined to establish their susceptibility to the most relevant antibiotics and chemiotherapeutics. As a basic requirement, the minimum inhibitory concentration (MIC) of the antimicrobials should be determined in order to distinguish susceptible and resistant strains. Strains carrying acquired resistance should not be used as a feed additives unless it can be demonstrated that it is a result of chromosomal mutation(s) [9].

\section{Methods}

\section{Bacterial isolates}

A total of 88 Lactobacillus isolates from fresh faeces or cloacae of 30 healthy chickens. Samples were collected from 2012 through 2013 from eight large-scale poultry farms (six broiler farms and two raising Green-legged Partridge hens) located in different parts of Poland, with three or four from each farm. The birds were from 2 to 49 days old. The number of Lactobacillus isolates derived from individual farms ranged from 7 to 17 . The bacterial isolates had previously been identified to the species level using MALDI-TOF mass spectrometry and Amplified 16S Ribosomal DNA Restriction Analysis (16S-ARDRA) [10]. Lactobacilli belonged to the species L. salivarius $(\mathrm{n}=31)$, L. johnsonii $(\mathrm{n}=21)$, L. crispatus $(\mathrm{n}=12), L$. reuteri $(\mathrm{n}=10)$, L. ingluviei $(\mathrm{n}=8)$, L. saerimneri $(\mathrm{n}=3)$ and L. agilis $(\mathrm{n}=3)$. 
The strains were stored in deMan Rogosa Sharpe broth (MRS, BTL, Poland) containing $20 \%$ glycerol at $-80{ }^{\circ} \mathrm{C}$. Prior to antimicrobial susceptibility testing the cultures were streaked on lactic acid bacteria (LAB) susceptibility test medium (LSM) [11] and incubated overnight at $37^{\circ} \mathrm{C}$ in $5 \% \mathrm{CO}_{2}$.

\section{Determination of minimal inhibitory concentration}

Antibiotic susceptibility of all bacterial isolates was determined by the broth microdilution procedure [12], using the LSM medium recommended by the International Organization of Standardization (ISO)/International Dairy Federation (IDF) [13].

All antimicrobial agent powders were obtained from Sigma-Aldrich (Poland). Enrofloxacin (Enrocin, $50 \mathrm{mg} /$ $\mathrm{ml}$ ) was purchased from Vet-Agro (Poland) and tiamulin (Biomutin, $200 \mathrm{mg} / \mathrm{ml}$ ) from BIOWET DRWALEW S.A. (Poland).

Inocula were prepared by suspending bacteria in $0.9 \%$ $\mathrm{NaCl}$ so that the optical density (OD) of the suspension at $600 \mathrm{~nm}$ was 0.5 . Microdilution plates were inoculated with $50-\mu$ of a 1:500-diluted (in LSM broth) inoculum and $50 \mu \mathrm{l}$ of the appropriate antibiotic concentration (stock solution previously dissolved in LSM), resulting in the final range of concentrations shown in Table 1. After the plates were incubated at $37{ }^{\circ} \mathrm{C}$ in $5 \% \mathrm{CO}_{2}$ for $48 \mathrm{~h}$, MIC values were read as the lowest concentration of an antimicrobial agent at which visible growth was inhibited.

The breakpoints for testing lactobacilli are not reported in the European Committee on Antimicrobial Susceptibility Testing (EUCAST) guidelines, and the procedure proposed by the CLSI $(\mathrm{M}-45)$ is not adapted to the growth requirements of all Lactobacillus species. Hence our interpretation of the results was based on the breakpoint values suggested by FEDAP [9] for ampicillin, tetracycline, erythromycin, streptomycin, gentamicin and chloramphenicol. For doxycycline and tylosin we adopted the breakpoints of tetracycline and erythromycin, respectively. For lincomycin, tiamulin and enrofloxacin we established cut-offs based on the distribution of MICs (bimodal) and the presence or absence of resistance genes. The bacteria were considered resistant if the MIC was $\geq 8 \mu \mathrm{g} / \mathrm{ml}$ for tiamulin, $\geq 32 \mu \mathrm{g} / \mathrm{ml}$ for lincomycin, and $\geq 64 \mu \mathrm{g} / \mathrm{ml}$ for enrofloxacin. No breakpoints for neomycin and flumequine were proposed since the MICs generally showed unimodal distribution.

\section{Detection of resistance genes}

Bacterial genomic DNA was isolated using a GeneMATRIX Bacterial \& Yeast Genomic DNA Purification Kit (Eurx, Poland), following the manufacturer's instructions with some modifications [10].

PCR reactions using gene-specific primers (Table 2) were used to detect the presence of 36 genes known to be involved in resistance to the antibiotics tested. Seven tetracycline and macrolide resistance genes (tet $M$, tet $K$, tet $L$, tet $O$, erm $A, e r m B$ and $m e f A / E$ ) and five aminoglycoside resistance genes (Table 2) were detected using multiplex PCR $[14,15]$.

The reaction mixture composition $(25 \mu \mathrm{l})$ for detection of other (single) resistance genes was as follows: $2.5 \mu \mathrm{l}$ PCR buffer $(200 \mathrm{mM}$ Tris- $\mathrm{HCl}, \mathrm{pH} 8.8,100 \mathrm{mM} \mathrm{KCl}$, $100 \mathrm{mM}\left(\mathrm{NH}_{4}\right)_{2} \mathrm{SO}_{4}, 1.0 \%$ Triton X-100), $1.5 \mu \mathrm{l} 8 \mathrm{mM}$ deoxynucleoside triphosphates (dNTPs, Blirt, Poland), $1 \mu \mathrm{l}$ of each of two primers $(10 \mathrm{pmol} / \mu \mathrm{l}$, Genomed, Poland), $0.15 \mu$ l Dream Taq DNA polymerase $(5 \mathrm{U} / \mathrm{ml}$,

Table 1 Antimicrobial substances and their dilutions used to determine MICs

\begin{tabular}{|c|c|c|c|}
\hline Antimicrobial substance & Group of antimicrobial agent & Diluent to prepare stock solution & Range of concentration $(\mu \mathrm{g} / \mathrm{ml})$ \\
\hline Ampicilin & $\beta$-Lactams & $\mathrm{BR} \|^{\mathrm{a}}$ & $0.125-64$ \\
\hline Tetracycline & Tetracyclines & $0.1 \mathrm{M} \mathrm{HCl}$ & $1-512$ \\
\hline Doxycycline & & & $0.5-256$ \\
\hline Erythromycin & Macrolides & Methanol 99.9\% & $0.125-64$ \\
\hline Tylosin & & $\mathrm{H}_{2} \mathrm{O}$ & $0.125-64$ \\
\hline Lincomycin & Lincosamides & & $2-1024$ \\
\hline Streptomycin & Aminoglicosides & $\mathrm{H}_{2} \mathrm{O}$ & $2-1024$ \\
\hline Gentamicin & & $\mathrm{BR} \|^{\mathrm{a}}$ & $1-512$ \\
\hline Neomycin & & $\mathrm{BR} \|^{\mathrm{a}}$ & $1-512$ \\
\hline Chloramphenicol & Chloramphenicol & Methanol 50\% & $0.5-256$ \\
\hline Tiamulin & Semisynthetic derivative of pleuromutilin & - & $0.5-256$ \\
\hline Enrofloxacin & Fluoroquinolones & - & $0.5-512$ \\
\hline Flumequine & & $0.1 \mathrm{M} \mathrm{NH}_{4} \mathrm{OH}$ & $2-1024$ \\
\hline
\end{tabular}

${ }^{a}$ BR II buffer: $16.73 \mathrm{~g} \mathrm{~K}_{2} \mathrm{HPO}_{4}$ and $0.523 \mathrm{~g} \mathrm{KH}_{2} \mathrm{PO}_{4}$ diluted in $1000 \mathrm{ml}$ of distilled $\mathrm{H}_{2} \mathrm{O}$, $\mathrm{pH} 7.9$ 
Table 2 Primers used for detection of selected antibiotic resistance genes

\begin{tabular}{|c|c|c|c|c|c|}
\hline $\begin{array}{l}\text { Determining } \\
\text { resistance to }\end{array}$ & Target gene & Primer sequence $\left(5^{\prime}-3^{\prime}\right)$ & $\begin{array}{l}\text { Amplicon } \\
\text { size (bp) }\end{array}$ & $\begin{array}{l}\text { Annealing } \\
\text { temperature }\left({ }^{\circ} \mathrm{C}\right)\end{array}$ & Reference \\
\hline \multirow[t]{6}{*}{ Tetracyclines } & tetM & $\begin{array}{l}\text { GTG GAC AAA GGT ACA ACG AG } \\
\text { CGG TAA AGT TCG TCA CAC AC }\end{array}$ & 406 & 60 & {$[14]$} \\
\hline & tetk & $\begin{array}{l}\text { GAT CAA TTG TAG CTT TAG GTG AAG G } \\
\text { TTTTGTTGA TTT ACC AGG TAC CATT }\end{array}$ & 155 & 60 & \\
\hline & tetl & $\begin{array}{l}\text { TGG TGG AAT GAT AGC CCA TT } \\
\text { CAG GAATGA CAG CAC GCT AA }\end{array}$ & 229 & 60 & \\
\hline & tetO & $\begin{array}{l}\text { AAC TTA GGC ATT CTG GCT CAC } \\
\text { TCC CAC TGTTCC ATA TCG TCA }\end{array}$ & 515 & 60 & \\
\hline & tetQ & $\begin{array}{l}\text { TTA TAC TTC CTC CGG CAT CG } \\
\text { ATC GGT TCG AGA ATG TCC AC }\end{array}$ & 904 & 55 & [64] \\
\hline & tetW & $\begin{array}{l}\text { GAG AGC CTG CTA TAT GCC AGC } \\
\text { GGG CGT ATC CAC AAT GTT AAC }\end{array}$ & 168 & 64 & {$[65]$} \\
\hline \multirow[t]{8}{*}{ Macrolides } & ermA & $\begin{array}{l}\text { CCC GAA AAA TAC GCA AAA TTT CAT } \\
\text { CCC TGT TTA CCC ATT TAT AAA CG }\end{array}$ & 590 & 60 & {$[14]$} \\
\hline & ermB & $\begin{array}{l}\text { TGG TAT TCC AAA TGC GTA ATG } \\
\text { CTG TGG TAT GGC GGG TAA GT }\end{array}$ & 745 & 60 & \\
\hline & ermC & $\begin{array}{l}\text { AAT CGT CAA TTC CTG CAT GT } \\
\text { TAATCGTGGAATACGGGTTTG }\end{array}$ & 299 & 58 & [31] \\
\hline & ermT & $\begin{array}{l}\text { TAT TAT TGA GATTGG TTC AGG G } \\
\text { GGA TGA AAG TAT TCT CTA GGG ATTT }\end{array}$ & 395 & 55 & [33] \\
\hline & $m s r A / B$ & $\begin{array}{l}\text { GCA AAT GGT GTA GGT AAG ACA ACT } \\
\text { ATC ATG TGA TGT AAA CAA AAT }\end{array}$ & 399 & 54 & {$[66]$} \\
\hline & msrC & $\begin{array}{l}\text { AAG GAA TCC TTC TCT CTC CG } \\
\text { GTA AAC AAA ATC GTT CCC G }\end{array}$ & 343 & 55 & {$[67]$} \\
\hline & mefA/E & $\begin{array}{l}\text { CAA TAT GGG CAG GGC AAG } \\
\text { AAG CTG TTC CAA TGC TAC GC }\end{array}$ & 317 & 60 & {$[14]$} \\
\hline & $\ln u A$ & $\begin{array}{l}\text { GGT GGC TGG GGG GTA GAT GTA TTA ACT GG } \\
\text { GCTTCTTTT GAA ATA CAT GGT ATTTTT CGA TC }\end{array}$ & 323 & 61 & [32] \\
\hline \multirow[t]{9}{*}{ Aminoglicosides } & $\operatorname{aac}\left(6^{\prime}\right)-1 e-a p h\left(2^{\prime \prime}\right)-1 a$ & $\begin{array}{l}\text { CAG AGC CTT GGG AAG ATG AAG } \\
\text { CCT CGT GTA ATT CAT GTT CTG GC }\end{array}$ & 348 & 57 & {$[15]$} \\
\hline & aph3IIIa & $\begin{array}{l}\text { GGC TAA AAT GAG AAT ATC ACC GG } \\
\text { CTT TAA AAA ATC ATA CAG CTC GCG }\end{array}$ & 523 & & \\
\hline & $\operatorname{ant}\left(4^{\prime}\right)-1 a$ & $\begin{array}{l}\text { CAA ACT GCT AAA TCG GTA GAA GCC } \\
\text { GGA AAG TTG ACC AGA CAT TAC GAA CT }\end{array}$ & 294 & & \\
\hline & $a p h\left(2^{\prime \prime}\right)-1 c$ & $\begin{array}{l}\text { CCA CAA TGA TAA TGA CTC AGT TCC C } \\
\text { CCA CAG CTT CCG ATA GCA AGA G }\end{array}$ & 444 & & \\
\hline & $\operatorname{aph}\left(2^{\prime \prime}\right)-1 d$ & $\begin{array}{l}\text { GTG GTT TTT ACA GGA ATG CCA TC } \\
\text { CCC TCTTCA TAC CAA TCC ATA TAA CC }\end{array}$ & 641 & & \\
\hline & ant(6)-la & $\begin{array}{l}\text { CGG GAG AAT GGG AGA CTT TG } \\
\text { CTG TGG CTC CAC AAT CTG AT }\end{array}$ & 563 & 56 & {$[54]$} \\
\hline & $\operatorname{aac}\left(6^{\prime}\right)-l i$ & $\begin{array}{l}\text { TGGCCGGAAGAATATGGAGA } \\
\text { GCATTTGGTAAGACACCTACG }\end{array}$ & 410 & 55 & \\
\hline & $\operatorname{aad} A$ & $\begin{array}{l}\text { ATC CTT CGG CGC GATTTT G } \\
\text { GCA GCG CAA TGA CATTCT TG }\end{array}$ & 282 & 55 & {$[47]$} \\
\hline & aadE & $\begin{array}{l}\text { ATG GAA TTA TTC CCA CCT GA } \\
\text { TCA AAA CCC CTA TTA AAG CC }\end{array}$ & 1100 & 51 & [51] \\
\hline Chloramphenicol & cat & $\begin{array}{l}\text { TAA GGTTAT TGG GAT AAG TTA } \\
\text { GCA TGR TAA CCA TCA CAW AC }\end{array}$ & $\sim 300$ & 54 & {$[18]$} \\
\hline \multirow[t]{3}{*}{ Tiamulin } & $c f r$ & $\begin{array}{l}\text { TGA AGT ATA AAG CAG GTT GGG AGT CA } \\
\text { ACC ATA TAA TTG ACC ACA AGC AGC }\end{array}$ & 746 & 58 & {$[68]$} \\
\hline & IsaE & $\begin{array}{l}\text { TGT CAA ATG GTG AGC AAA CG } \\
\text { TGT AAA ACG GCT TCC TGA TG }\end{array}$ & 496 & 54 & [69] \\
\hline & IsaC & $\begin{array}{l}\text { GGC TAT GTA AAA CCT GTA TTT G } \\
\text { ACT GAC AATTTT TCT TCC GT }\end{array}$ & 429 & 50 & {$[70]$} \\
\hline
\end{tabular}


Table 2 continued

\begin{tabular}{|c|c|c|c|c|c|}
\hline $\begin{array}{l}\text { Determining } \\
\text { resistance to }\end{array}$ & Target gene & Primer sequence $\left(5^{\prime}-3^{\prime}\right)$ & $\begin{array}{l}\text { Amplicon } \\
\text { size (bp) }\end{array}$ & $\begin{array}{l}\text { Annealing } \\
\text { temperature }\left({ }^{\circ} \mathrm{C}\right)\end{array}$ & Reference \\
\hline & $\operatorname{vgaA}$ & $\begin{array}{l}\text { AGT GGT GGT GAA GTA ACA CG } \\
\text { CTC TTG TTC TAA TTC TTC CG }\end{array}$ & 1287 & 53 & {$[70]$} \\
\hline & $v g a A v$ & $\begin{array}{l}\text { CTC CGT GTT GAA GAT GTT TCG } \\
\text { GGA TTC AAA CGC CTC TAT AGC C }\end{array}$ & 459 & 56 & {$[71]$} \\
\hline \multirow[t]{3}{*}{ Penicillins } & blaz & $\begin{array}{l}\text { ACT TCA ACA CCT GCT GCT TTC } \\
\text { TAG GTT CAG ATT GGC CCTTAG }\end{array}$ & 240 & 60 & {$[72]$} \\
\hline & mecA & $\begin{array}{l}\text { AGT TCT GCA GTA CCG GAT TTG C } \\
\text { AAA ATC GAT GGT AAA GGT TGG C }\end{array}$ & 533 & 55 & [73] \\
\hline & pbp5 & $\begin{array}{l}\text { AAC AAA ATG ACA AAC GGG } \\
\text { TAT CCT TGG TTA TCA GGG }\end{array}$ & 779 & 52 & [74] \\
\hline \multirow[t]{4}{*}{ Many antibiotics } & $a c r A$ & $\begin{array}{l}\text { CTC TCA GGC AGC TTA GCC CTA A } \\
\text { TGC AGA GGT TCA GTTTTG ACT GTT }\end{array}$ & 107 & 58 & {$[58]$} \\
\hline & mdeA & $\begin{array}{l}\text { CTT TCA GGT TAC CTT GTT GAA TAT TTA AAC } \\
\text { ATC AAT AGG TAC TTT AAT TGT AGT TCC AAC }\end{array}$ & 180 & 56 & {$[75]$} \\
\hline & norA & $\begin{array}{l}\text { TTT GTT TTC AGT GTC AGA ATT TAT GTT TG } \\
\text { GGC TTG GTG AAA TAT CAG CTA TTA AAC }\end{array}$ & 140 & 56 & \\
\hline & mepA & $\begin{array}{l}\text { ATG GTA TAG GTT TCT TGT TTA CTG GTA TG } \\
\text { AAT GAT AAT TGC ACC TTG TAA AAT GGC }\end{array}$ & 150 & 57 & \\
\hline
\end{tabular}

Thermo Scientific), $1 \mu$ l template DNA ( 20 ng) and $17.8 \mu$ l deionized water (Sigma, Poland).

All PCR reactions were performed in an Eppendorf Mastercycler using the following temperature program: initial denaturation at $94{ }^{\circ} \mathrm{C}$ for $5 \mathrm{~min}, 30$ cycles of $94{ }^{\circ} \mathrm{C}$ for $45 \mathrm{~s}, 50-64{ }^{\circ} \mathrm{C}$ (according to the annealing temperature for the individual primers; Table 2) for $45 \mathrm{~s}, 72^{\circ} \mathrm{C}$ for $75 \mathrm{~s}$ and a final extension step at $72{ }^{\circ} \mathrm{C}$ for $8 \mathrm{~min}$. PCR products $(8 \mu \mathrm{l})$ were separated by electrophoresis $(100 \mathrm{~V})$ on $2 \%$ agarose gels and visualized by ethidium bromide staining.

\section{Nitrocefin test}

Production of $\beta$-lactamase was tested by streaking the bacterial colonies onto nitrocefin strips (DIAGNOSTICS Inc., Slovak Republic). The lactobacilli used in the test had been grown overnight on MRSA agar around a ampicillin disc (induction of production of $\beta$-lactamases). A change in colour from light yellow to red within $10 \mathrm{~min}$ at room temperature was identified as hydrolysis of the $\beta$-lactam antibiotic by the induced $\beta$-lactamase. As a positive control we used three wild $E$. coli isolates containing the $b l a_{\text {TEM-1 }}$ gene (detection of bla ${ }_{\text {TEM-1 }}$ was performed according to Van et al. [16]).

\section{Results}

\section{Antimicrobial susceptibility testing}

The MIC of 13 antibiotic agents was analysed for $88 \mathrm{Lac}$ tobacillus strains isolated from chickens. The MIC range was $\leq 0.25$ to $>64 \mu \mathrm{g} / \mathrm{ml}$ for ampicillin, $\leq 1-512 \mu \mathrm{g} / \mathrm{ml}$ for tetracyclines, $\leq 0.25$ to $>64 \mu \mathrm{g} / \mathrm{ml}$ for macrolides, $\leq 2$ to
$>1024 \mu \mathrm{g} / \mathrm{ml}$ for lincomycin, $\leq 1$ to $>1024 \mu \mathrm{g} / \mathrm{ml}$ for aminoglycosides, 1 to $64 \mu \mathrm{g} / \mathrm{ml}$ for chloramphenicol, $\leq 0.5$ to $>256 \mu \mathrm{g} / \mathrm{ml}$ for tiamulin, and 2 to $512 \mu \mathrm{g} / \mathrm{ml}$ for fluoroquinolones (Table 3).

According to the established criteria, $90 \%$ of isolates were resistant to tiamulin, $74 \%$ to tetracycline, $72 \%$ to doxycycline, $70 \%$ to lincomycin, $48 \%$ to enrofloxacin, $42 \%$ to erythromycin and tylosin, $31 \%$ to streptomycin, $26 \%$ to ampicillin, $23 \%$ to chloramphenicol, and $12.5 \%$ to gentamicin (Table 4). As many as $98 \%$ of Lactobacillus isolates showed resistance to at least one antimicrobial agent. Multiple-drug resistance was observed for $79.5 \%$ of lactobacilli (Table 4). Seven isolates (8\%; L. salivarius $8 \mathrm{a}, 9 \mathrm{~b}$, L. johnsonii 3c, 4b, 8f, L. agilis 6 days and $8 \mathrm{~h}$ ) were resistant to only one antibiotic, and in all cases it was tiamulin (MIC $\geq 8 \mu \mathrm{g} / \mathrm{ml}$ ). Only two L. ingluviei isolates (Ch9e, Ch43d) showed susceptibility to all the drugs tested (the analysis did not include neomycin or flumequine).

The ampicillin-resistant isolates (23) belonged to different Lactobacillus species. The highest MIC values, i.e. $>64 \mu \mathrm{g} / \mathrm{ml}$, were observed for 5 isolates of L. johnsonii and L. crispatus, with clear bimodal distribution of MICs noted only for L. johnsonii isolates. In the case of L. crispatus we noted three MIC ranges -05 to $1 \mu \mathrm{g} / \mathrm{ml}, 4$ to $8 \mu \mathrm{g} / \mathrm{ml}$ and 32 to $>64 \mu \mathrm{g} / \mathrm{ml}$, which could indicate the presence of sensitive, intermediate and resistant strains (Table 3).

Clear bimodal distribution of MICs indicative of acquired resistance was observed for macrolides, where the bimodal distribution obtained indicated 
Table 3 Distribution of MICs of antibiotics among various Lactobacillus species of chicken origin

\begin{tabular}{|c|c|c|c|c|c|c|c|c|c|c|c|c|c|c|c|c|c|c|}
\hline \multirow{2}{*}{\multicolumn{19}{|c|}{ Ampicillin }} \\
\hline & & & & & & & & & & & & & & & & & & \\
\hline L. salivarius $(\mathrm{n}=31)$ & & & & 9 & & 14 & & 3 & 1 & 2 & 2 & & & & & & & \\
\hline L. agilis $(\mathrm{n}=3)$ & & 3 & & & & & & & & & & & & & & & & \\
\hline L. johnsonii $(\mathrm{n}=21)$ & & & & 3 & & 12 & & 3 & & & & & & 3 & & & & \\
\hline L. crispatus $(\mathrm{n}=12)$ & & & & 2 & & 2 & & & 2 & 3 & & 1 & & 2 & & & & \\
\hline L. reuteri $(\mathrm{n}=10)$ & & & & & & 3 & & 2 & 2 & 3 & & & & & & & & \\
\hline L. ingluviei $(\mathrm{n}=8)$ & & & & 4 & & 3 & & 1 & & & & & & & & & & \\
\hline L. saerimneri $(n=3)$ & & & & 2 & & 1 & & & & & & & & & & & & \\
\hline All & & 3 & & 20 & & 35 & & 9 & 5 & 8 & 2 & 1 & & 5 & & & & \\
\hline Tetracycline & & & & & & & & & & & & & & & & & & \\
\hline L. salivarius $(\mathrm{n}=31)$ & & & & & 2 & 1 & & 2 & & 3 & & & $1^{\operatorname{tet}^{*}}$ & & $5^{\text {tet }}$ & $10^{\text {tet }}$ & $7^{\text {tet }}$ & \\
\hline L. agilis $(n=3)$ & & & & & 2 & & & & & & & & & & & $1^{\text {tet }}$ & & \\
\hline L. johnsonii $(n=21)$ & & & & & 4 & & & 1 & 2 & 1 & & $1^{\text {tet }}$ & $3^{\text {tet }}$ & & $7^{\text {tet }}$ & $2^{\text {tet }}$ & & \\
\hline L. crispatus $(\mathrm{n}=12$ ) & & & & & 1 & 1 & & 1 & & & & & $5^{\text {tet }}$ & & & $4^{\operatorname{tet}(3)}$ & & \\
\hline L. reuteri $(\mathrm{n}=10)$ & & & & & & & & & & & 1 & & & & & $5^{\text {tet }}$ & $4^{\text {tet }}$ & \\
\hline L. ingluviei $(\mathrm{n}=8)$ & & & & & 1 & & & & & & 1 & 1 & & & & $1^{\text {tet }}$ & $4^{\text {tet }}$ & \\
\hline L. saerimneri $(n=3)$ & & & & & 1 & & & & & & & & $1^{\text {tet }}$ & & $1^{\text {tet }}$ & & & \\
\hline All & & & & & 11 & 2 & & 4 & 2 & 4 & 2 & 2 & 10 & & 13 & 23 & 15 & \\
\hline Doxycycline & & & & & & & & & & & & & & & & & & \\
\hline L. salivarius $(n=31)$ & & & & & 4 & & & 1 & 2 & 1 & & $3^{\text {tet }}$ & $5^{\text {tet }}$ & & $15^{\text {tet }}$ & & & \\
\hline L. agilis $(\mathrm{n}=3)$ & & & & & 2 & & & & & & & & $1^{\text {tet }}$ & & & & & \\
\hline L. johnsonii $(\mathrm{n}=21)$ & & & & & 4 & 1 & & 2 & & & $1^{\text {tet }}$ & & $13^{\text {tet }}$ & & & & & \\
\hline L. crispatus $(n=12)$ & & & & & 3 & & & & & & & & $7^{\text {tet }}$ & & $1^{\text {tet }}$ & 1 & & \\
\hline L. reuteri $(n=10)$ & & & & & & & & & & 1 & & & & & $2^{\text {tet }}$ & $7^{\text {tet }}$ & & \\
\hline L. ingluviei $(\mathrm{n}=8)$ & & & & & & & & & 1 & 2 & & & $2^{\text {tet }}$ & & $2^{\text {tet }}$ & $1^{\text {tet }}$ & & \\
\hline L. saerimneri $(n=3)$ & & & & & 1 & & & & & & & & $2^{\text {tet }}$ & & & & & \\
\hline All & & & & & 14 & 1 & & 3 & 3 & 4 & 1 & 3 & 30 & & 20 & 9 & & \\
\hline
\end{tabular}

Erythromycin

\begin{tabular}{|c|c|c|c|c|c|c|}
\hline L. salivarius $(\mathrm{n}=31)$ & 1 & 1 & \multicolumn{2}{|l|}{11} & \multirow{2}{*}{\multicolumn{2}{|c|}{$\begin{array}{c}18 \\
\operatorname{ermC}(5) \\
\operatorname{ermB}(16)\end{array}$}} \\
\hline L. agilis $(n=3)$ & 2 & $1^{\mathrm{erm} C}$ & & & & \\
\hline L. johnsonii $(\mathrm{n}=21)$ & 92 & $2^{\mathrm{ermB}(1)}$ & & & $1^{\mathrm{erm} B}$ & $9^{\operatorname{erm} B(8)}$ \\
\hline L. crispatus $(n=12)$ & $8^{\mathrm{erm} C(1)}$ & 1 & & & & $3^{\mathrm{ermB}(2)}$ \\
\hline L. reuteri $(\mathrm{n}=10)$ & 2 & 3 & & 1 & & $4^{\mathrm{ermB},}$ \\
\hline L. ingluviei $(\mathrm{n}=8)$ & 1 & 5 & 1 & & & $1^{\mathrm{ermB}}$ \\
\hline L. saerimneri $(n=3)$ & $1^{\text {ermc }}$ & $1^{\text {erm } C}$ & & & & $1^{\mathrm{ermB}}$ \\
\hline All & 24 & 14 & 12 & 1 & 1 & 36 \\
\hline \multicolumn{7}{|l|}{ Tylosin } \\
\hline \multirow[t]{2}{*}{ L. salivarius $(\mathrm{n}=31)$} & 1 & 5 & 7 & & $1^{\mathrm{ermB}}$ & $17^{\mathrm{erm} C(5)}$ \\
\hline & & & & & & ermB(15) \\
\hline L. agilis $(n=3)$ & $3^{\text {erm } C(1)}$ & & & & & \\
\hline L. johnsonii $(n=21)$ & $\begin{array}{c}10 \\
\operatorname{ermB}(1)\end{array}$ & 1 & & & & $1^{\text {ermB }} 9^{\text {ermB(8) }}$ \\
\hline L. crispatus $(n=12)$ & $8^{e r m C(1)}$ & 1 & & & & $3^{\operatorname{ermB(2)}}$ \\
\hline L. reuteri $(n=10)$ & 2 & 3 & $1^{\text {ermc }}$ & & & $\begin{array}{l}4^{\text {ermB }} \\
\text { ermC(1) }\end{array}$ \\
\hline L. ingluviei $(\mathrm{n}=8)$ & 3 & 2 & 2 & & & $1^{\mathrm{ermB}}$ \\
\hline L. saerimneri $(\mathrm{n}=3)$ & $2^{e r m C(1)}$ & & & & & $1^{\text {ermB }}$ \\
\hline All & 29 & 12 & 10 & & 1 & 35 \\
\hline
\end{tabular}

Lincomycin

L. salivarius $(\mathrm{n}=31)$

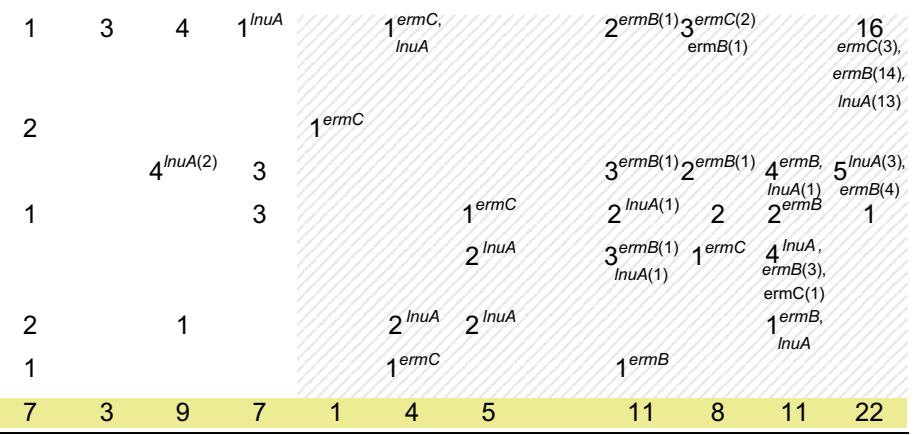

\begin{tabular}{|c|c|c|c|c|c|c|c|c|c|c|c|}
\hline L. agilis $(\mathrm{n}=3)$ & 2 & & & & ermc & & & & & & $\operatorname{In} u A(13)$ \\
\hline L. johnsonii $(n=21)$ & & & $4^{\ln u A(2)}$ & 3 & & & & $3^{\mathrm{ermB}(1)}$ & ermB(1) & ${ }_{\ln u A(1)}^{e r m B,}$ & $\begin{array}{l}5_{\text {erm } B(4)}^{\ln A(3)} \\
\text {, }\end{array}$ \\
\hline L. crispatus $(\mathrm{n}=12)$ & 1 & & & 3 & & & $1^{\text {ermc }}$ & $2^{\ln u A(1)}$ & 2 & $2^{\text {ermB }}$ & 1 \\
\hline L. reuteri $(n=10)$ & & & & & & & $2^{\ln u A}$ & $\begin{array}{l}3^{\operatorname{erm} B(1)} \\
\ln u A(1)\end{array}$ & $1^{\mathrm{erm} C}$ & $\begin{array}{l}4^{\operatorname{In} u A}, \\
\operatorname{erm} B(3), \\
\operatorname{ermC}(1)\end{array}$ & \\
\hline L. ingluviei $(\mathrm{n}=8)$ & 2 & & 1 & & & $2^{\ln u A}$ & $2^{\operatorname{In} u A}$ & & & $1^{\mathrm{ermB},}$ & \\
\hline L. saerimneri $(n=3)$ & 1 & & & & & $1^{\mathrm{erm} C}$ & & $1^{\mathrm{erm} B}$ & & & \\
\hline All & 7 & 3 & 9 & 7 & 1 & 4 & 5 & 11 & 8 & 11 & 22 \\
\hline
\end{tabular}


Table 3 continued

\begin{tabular}{|c|c|c|c|c|c|c|c|c|c|c|c|c|c|c|c|}
\hline \multicolumn{16}{|l|}{ Streptomycin } \\
\hline L. salivarius $(\mathrm{n}=31$ ) & & & & & & & & & & $\begin{array}{l}1_{\text {antfla* }}^{\text {aad }} \\
\text { * }\end{array}$ & 14 & $\begin{array}{c}11 \\
\text { antfla(2) }\end{array}$ & & $\begin{array}{l}1_{\text {ant6la }}^{\text {aad }} \\
\text {, }\end{array}$ & $\underset{\operatorname{aad} E(2)}{4}$ \\
\hline L. agilis $(\mathrm{n}=3)$ & & & & & & & & & & & 2 & 1 & & & \\
\hline L. johnsonii $(n=21)$ & & & & & 6 & 4 & 5 & 1 & 2 & 3 & & & & & \\
\hline L. crispatus $(\mathrm{n}=12)$ & & & & & 4 & & 3 & & 1 & & 2 & & & & \\
\hline L. reuteri $(n=10)$ & & & & & & & & 1 & 4 & 2 & 1 & 2 & & & \\
\hline L. ingluviei $(\mathrm{n}=8)$ & & & & & & & 1 & & & 1 & $\underset{\text { ant6la(1) }}{6}$ & & & & \\
\hline L. saerimneri $(\mathrm{n}=3)$ & & & & & & & & & & 1 & 1 & 1 & & & \\
\hline All & & & & & 10 & 4 & 9 & 4 & 7 & 8 & 26 & 15 & & 1 & 4 \\
\hline \multicolumn{16}{|l|}{ Gentamicin } \\
\hline L. salivarius $(n=31)$ & & & & & & & 3 & $\begin{array}{l}17^{\text {bifi* }^{*}(1),} \\
\operatorname{aph}_{21 \mathrm{l}(1)^{*}}\end{array}$ & 5 & & & $1^{\text {bif }}$ & $\begin{array}{l}3^{\text {bif, }} \\
\text { aph2lc(2) a }\end{array}$ & ${ }_{\text {aph2lc(1) }}^{\operatorname{bof}^{\mathrm{bi}(1),}}$ & \\
\hline L. agilis $(\mathrm{n}=3)$ & & & & & & & 1 & 1 & & 1 & & & & & \\
\hline L. johnsonii $(\mathrm{n}=21)$ & & & & & & & 11 & 9 & 1 & & & & & & \\
\hline L. crispatus ( $n=12$ ) & & & & & & 1 & 4 & $4^{\mathrm{bif}(1)}$ & 1 & 1 & 1 & & & & \\
\hline L. reuteri $(n=10)$ & & & 7 & & & 1 & 1 & 1 & & & & & & & \\
\hline L. ingluviei $(n=8)$ & & & & & & & 3 & 4 & 1 & & & & & & \\
\hline L. saerimneri $(\mathrm{n}=3)$ & & & & & & & & & 1 & $\underset{\text { aph } 2 c(1)}{2}$ & & & & & \\
\hline All & & & 7 & & & 2 & 23 & 36 & 9 & 4 & 1 & 1 & 3 & 2 & \\
\hline \multicolumn{16}{|l|}{ Neomycin } \\
\hline L. salivarius $(n=31)$ & & & & & & 4 & 4 & 15 & 6 & 2 & & & & & \\
\hline L. agilis $(\mathrm{n}=3)$ & & & & & & & 3 & & & & & & & & \\
\hline L. johnsonii $(n=21)$ & & & & & & & & 7 & 6 & 8 & & & & & \\
\hline L. crispatus $(\mathrm{n}=12$ ) & & & & & & & & 4 & 4 & 4 & & & & & \\
\hline L. reuteri $(n=10)$ & & & 7 & 1 & & 1 & & & 1 & & & & & & \\
\hline L. ingluviei $(\mathrm{n}=8)$ & & & & & & 5 & 3 & & & & & & & & \\
\hline L. saerimneri $(\mathrm{n}=3)$ & & & & & & & & & & 2 & & 1 & & & \\
\hline All & & & 7 & 1 & & 10 & 10 & 26 & 17 & 16 & & 1 & & & \\
\hline \multirow{2}{*}{\multicolumn{16}{|c|}{$\begin{array}{l}\text { Chloramphenicol } \\
\text { L. salivarius }(n=31)\end{array}$}} \\
\hline & & & & & & 2 & $13^{\operatorname{cat}(3)}$ & 3) $16^{\text {cat(5) }}$ & & & & & & & \\
\hline L. agilis $(n=3)$ & & & & & & 1 & 2 & & & & & & & & \\
\hline L. johnsonii $(n=21)$ & & & & & & $5^{\operatorname{cat}(4)}$ & $14^{\text {cat(5) }}$ & 5) $2^{\text {cat(2) }}$ & & & & & & & \\
\hline L. crispatus $(\mathrm{n}=12)$ & & & & & & $8^{\text {cat(5) }}$ & $3^{\text {cat }}$ & & & & 1 & & & & \\
\hline L. reuteri $(\mathrm{n}=10)$ & & & & 1 & & $1^{\text {cat }}$ & $7^{\operatorname{cat}(3)}$ & & $1^{\text {cat }}$ & & & & & & \\
\hline L. ingluviei $(\mathrm{n}=8)$ & & & & & & & $8^{\operatorname{cat}(1)}$ & & & & & & & & \\
\hline L. saerimneri $(\mathrm{n}=3)$ & & & & & & 2 & 1 & & & & & & & & \\
\hline All & & & & 1 & & 19 & 48 & 18 & 1 & & 1 & & & & \\
\hline \multicolumn{16}{|l|}{ Tiamulin } \\
\hline L. salivarius $(\mathrm{n}=31)$ & 2 & & & & & & & 1 & & 1 & $\underset{I s a E(1)}{4}$ & $\begin{array}{c}19 \\
\operatorname{IsaE}(6)\end{array}$ & $\begin{array}{l}4 \\
\text { IsaE(1) }\end{array}$ & & \\
\hline L. agilis $(n=3)$ & & & & & & 1 & & & 2 & & & & & & \\
\hline L. johnsonii $(\mathrm{n}=21)$ & & & & & & & & & & 1 & 8 & 11 & 1 & & \\
\hline L. crispatus $(\mathrm{n}=12)$ & & & & & & & & & & 5 & 3 & 4 & & & \\
\hline L. reuteri $(\mathrm{n}=10)$ & 2 & 1 & & & & & & 1 & 3 & 1 & & 2 & & & \\
\hline L. ingluviei $(\mathrm{n}=8)$ & 3 & & & & & & & & & & $5^{\operatorname{lsaE}(1)}$ & & & & \\
\hline L. saerimneri $(n=3)$ & & & & & & & & & 1 & 2 & & & & & \\
\hline All & 7 & 1 & & & & 1 & & 2 & 6 & 10 & 20 & 36 & 5 & & \\
\hline \multicolumn{16}{|l|}{ Enrofloxacin } \\
\hline L. salivarius $(n=31)$ & & & & & & 6 & 3 & 2 & 1 & 1 & 1 & 10 & 7 & & \\
\hline L. agilis $(n=3)$ & & & & & & & 2 & & & & & 1 & & & \\
\hline L. johnsonii $(n=21)$ & & & & & & & & 1 & 1 & 9 & 9 & 1 & & & \\
\hline L. crispatus $(\mathrm{n}=12)$ & & & & & & 1 & & & & & 2 & 7 & 2 & & \\
\hline L. reuteri $(n=10)$ & & & & & & & & 4 & 5 & & 1 & & & & \\
\hline L. ingluviei $(\mathrm{n}=8)$ & & & & & & & & 1 & 5 & 2 & & & & & \\
\hline L. saerimneri $(\mathrm{n}=3)$ & & & & & & 1 & 1 & & & & & 1 & & & \\
\hline \multirow{2}{*}{\multicolumn{16}{|c|}{ Flumequine }} \\
\hline & & & & & & & & & & & & & & & \\
\hline L. salivarius $(\mathrm{n}=31)$ & & & & & & & & 1 & 1 & 4 & 7 & 14 & 4 & & \\
\hline L. agilis $(n=3)$ & & & & & & & & & & 3 & & & & & \\
\hline L. johnsonii $(\mathrm{n}=21)$ & & & & & & & & & & & 1 & 5 & 12 & 3 & \\
\hline L. crispatus $(\mathrm{n}=12)$ & & & & & & & & & & & & 1 & 6 & 5 & \\
\hline L. reuteri $(n=10)$ & & & & & & & & & & 4 & 6 & & & & \\
\hline L. ingluviei $(\mathrm{n}=8)$ & & & & & & & & 2 & 5 & & & 1 & & & \\
\hline L. saerimneri $(n=3)$ & & & & & & & & & 1 & 2 & & & & & \\
\hline All & & & & & & & & 3 & 7 & 13 & 14 & 21 & 22 & 8 & \\
\hline
\end{tabular}

Fragments highlighted in grey indicate MIC cut-off values $(\mu \mathrm{g} / \mathrm{ml})$ proposed by the EFSA [9], and strips highlighted in grey (for doxycycline, tylosin, lincomycin, tiamulin and enrofloxacin) indicate MIC cut-off values proposed by us. The number of strains carrying the gene in question is given in brackets after the name of the gene. The absence of any number following the name of the gene means that all isolates contain the gene; tet ${ }^{*}=\operatorname{tet} M$ or tetL or tetW; bif* $=a a c\left(6^{\prime}\right)-l e-a p h\left(2^{\prime \prime}\right)-l a$; $a^{a}+6 l a^{*}=\operatorname{ant}(6)-I a ; a p h 2 l c^{*}=a p h\left(2^{\prime \prime}\right)-l c$ 
two subpopulations: one susceptible, with low MICs $(\leq 0.25-1 \mu \mathrm{g} / \mathrm{ml})$, and the other resistant, with high MICs (32 to $>64 \mu \mathrm{g} / \mathrm{ml}$ ). Similar clear bimodal distribution of MICs was noted for tiamulin for four species-L. salivarius, L. agilis, L. reuteri and L. ingluviei, and the MIC of 8 isolates was only $\leq 0.5 \mu \mathrm{g} / \mathrm{ml}$ (Table 3 ).

In the case of tetracyclines, lincomycin and enrofloxacin, bimodal distribution of MICs was observed for most Lactobacillus species, but was not as clearly bimodal as for macrolides (Table 3).

In the case of aminoglycosides, chloramphenicol and flumequine, the MIC values were distributed unimodally for most Lactobacillus species. Clear bimodal distribution was observed only in the case of gentamicin for $L$. salivarius, streptomycin and flumequine for $L$. inglu$v i e i$, neomycin for L. reuteri, and chloramphenicol for $L$. crispatus. Large differences were noted between Lactobacillus species in terms of their susceptibility to streptomycin. High MIC values $\geq 32 \mu \mathrm{g} / \mathrm{ml}$ characterised $L$. salivarius and L. saerimneri isolates, while for L. johnsonii and L. crispatus MICs were in the range of $\leq 2-64 \mu \mathrm{g} /$ $\mathrm{ml}$. The high sensitivity of most $L$. reuteri isolates to gentamicin and neomycin (MIC $\leq 1 \mu \mathrm{g} / \mathrm{ml}$ ) should also be highlighted (Table 3).

Lactobacilli exhibited cross-resistance to antibiotics belonging to the same chemical groups; $74 \%$ of strains were simultaneously resistant to tetracycline and doxycycline, $42 \%$ showed cross-resistance between erythromycin and tylosin, and for $42 \%$ (37) of lactobacilli cross-resistance was observed between macrolides and lincosamides. Simultaneous resistance to streptomycin and gentamicin was recorded for $9 \%$ of isolates (Table 4).

\section{Detection of antibiotic resistance genes}

To explain the mechanism responsible for the resistance phenotypes observed, all Lactobacillus isolates were screened by PCR for the presence of genetic determinants of resistance to the antibiotic agents tested.

Thirteen of the 36 investigated resistance genes were detected in the lactobacilli. All isolates contained efflux pump gene acrA. We found tet genes in 61 of 65 isolates showing a tetracycline resistance phenotype (MICs $\geq 8$ or $\geq 16$ or $\geq 32 \mu \mathrm{g} / \mathrm{ml}$ ). The most frequently occurring tet gene was tet $\mathrm{W}$, which was observed in $45 \%$ of isolates, followed by tet $\mathrm{M}(26 \%)$ and tet $\mathrm{L}(24 \%)$. The tet $\mathrm{W}$ gene was noted in $L$. reuteri strains ( $90 \%$ of isolates contained tet $\mathrm{W})$, L. ingluviei (75\%), L. saerimneri (67\%), L. johnsonii $(62 \%)$ and L. crispatus (58\%), but not in the L. salivarius isolates. The presence of the tet $\mathrm{M}$ and tet $\mathrm{L}$ genes was characteristic for $L$. salivarius, as $68 \%$ of isolates contained tet $\mathrm{M}, 61 \%$ carried tet $\mathrm{L}$ and $58 \%$ had both genes (Tables 3, 5). Co-occurrence of the tet $\mathrm{L}$, tet $\mathrm{M}$ and tet $\mathrm{W}$ genes was observed in only one isolate.
The genes ermB, erm C (coding methylases) and $\ln u A$ (coding lincosamide $O$-nucleotidyltransferase), associated with resistance to macrolides and lincosamides, were present in 39, 12 and 39\% of isolates, respectively. The ermB gene occurred in all isolates resistant to erythromycin and tylosin (37 isolates, MIC $\geq 32 \mu \mathrm{g} / \mathrm{ml}$ ) and in 34 of 62 isolates considered resistant to lincomycin $(\mathrm{MIC} \geq 16 \mu \mathrm{g} / \mathrm{ml})$. Thirty-three isolates containing ermB showed cross-resistance to macrolides and lincosamides, and one isolate (L. johnsonii) carrying ermB was susceptible to macrolides but resistant to lincomycin. The ermB gene was mainly present in strains of $L$. salivarius (53\%) and $L$. reuteri (40\%). The erm $C$ gene was detected in 11 isolates (12\%) of various Lactobacillus species. All the erm $C$-carrying isolates showed phenotypic resistance to lincomycin, but 6 of them were susceptible to macrolides. The $\ln u A$ gene was detected in 34 strains, including 31 of 62 strains that were resistant to lincomycin and 3 that were susceptible to it (Tables 3,5 ).

Genes determining resistance to aminoglycoside antibiotics were detected in 15 isolates (17\%), belonging mainly to the genus $L$. salivarius. The most common were $\operatorname{ant}(6)$-Ia (10\% of isolates) and aac(6 $\left.6^{\prime}\right)$-Ie-aph $\left(2^{\prime}\right)$ Ia (8\%), followed by aph(2")-Ic (6\%) and aadE (4.5\%). These genes occurred in both phenotypically resistant and sensitive isolates belonging to the species $L$. salivarius, $L$. crispatus, L. ingluviei and L. saerimneri. The gene aac(6')-Ie-aph(2')-Ia encoding bifunctional aminoglycoside-modifying enzyme, which confers high-level resistance to gentamicin [17], was present in 7 isolates (6 isolates of $L$. salivarius and one of L. crispatus), 4 of which exhibited phenotypic resistance to gentamicin. The gene $\operatorname{aph}\left(2^{\prime \prime}\right)-I c$ was detected in 3 isolates of $L$. salivarius and one L. saerimneri isolate showing resistance to gentamicin and in one gentamicin-susceptible isolate of $L$. salivarius. The presence of ant(6)-Ia and $a a d E$ genes encoding ANT(6) adenyltransferases, which determine resistance to streptomycin [17], was noted in 11 isolates (9 of L. salivarius, one L. reuteri and one L. ingluviei). The ant(6)-Ia gene was present in 7 of 24 streptomycinresistant isolates and in 2 isolates considered to be streptomycin-susceptible. Four L. salivarius isolates, including 3 streptomycin-resistant and one streptomycin-susceptible, contained both the ant(6)-Ia and $a a d E$ genes (Tables 3, 5).

The cat gene encoding chloramphenicol acetyltransferase, which converts chloramphenicol to inactive diacetyl chloramphenicol [18], was present in 32 isolates (36\%), including 8 of 20 found to be resistant to chloramphenicol (MIC $\leq 8 \mu \mathrm{g} / \mathrm{ml}$ ) (Tables 3, 5).

In PCR using lsaE-specific primers, we obtained a single product for 20 isolates, but with varying product size-496 bp for 8 isolates of L. salivarius and 2 of 


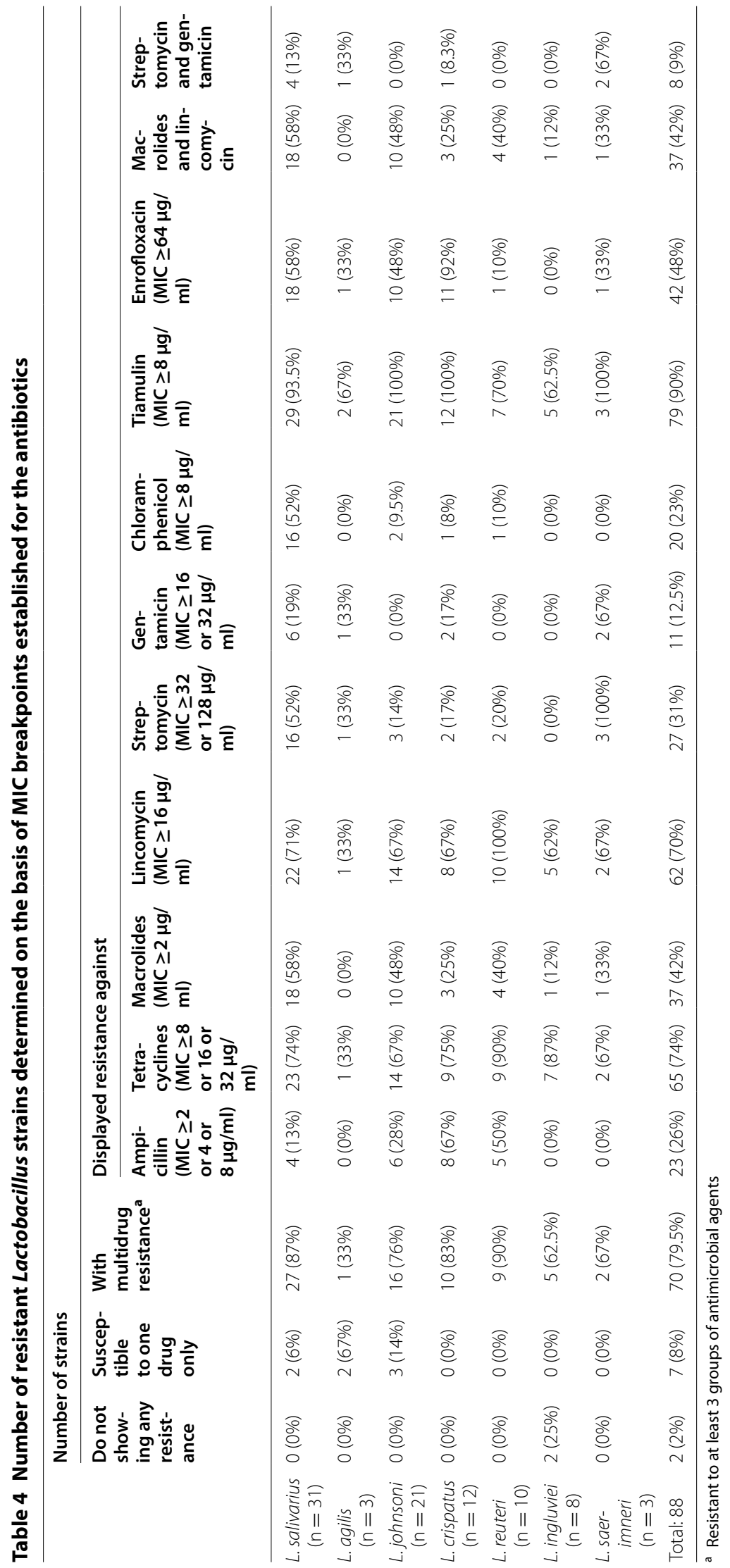




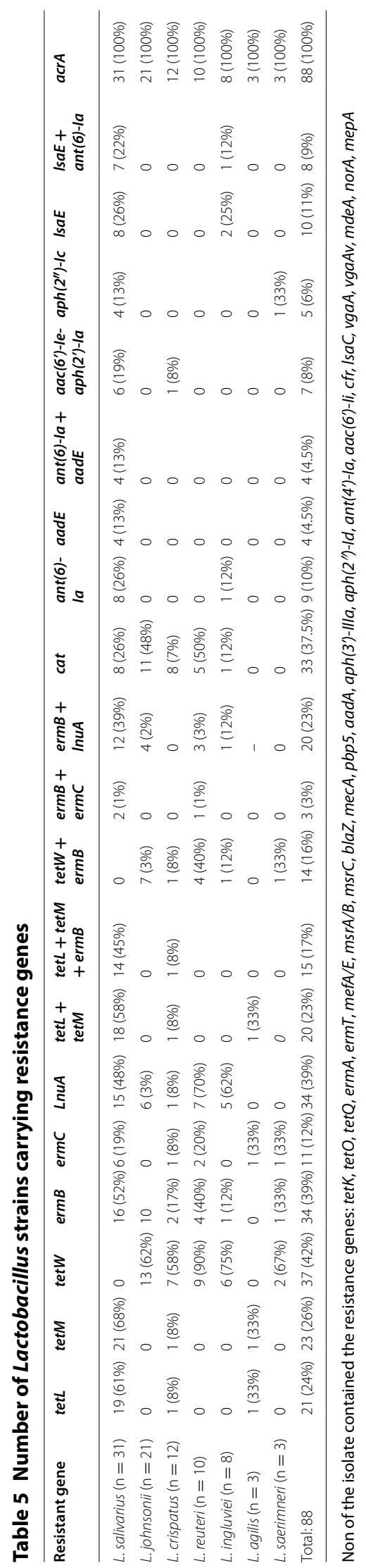


L. ingluviei, and $570 \mathrm{bp}$ for 10 isolates of L. johnsonii. Therefore we sequenced representative PCR products of both sizes. Only the PCR product of $496 \mathrm{bp}$ (GenBank Accession No. KY924692) showed 99\% similarity (NCBI BLAST algorithm) to the the $l s a E$ gene sequence of Enterococcus faecalis deposited in GenBank (Accession Nos. KX156279.1, KX156278.1 and NG_047935.1). The lsaE gene was present in 10 of 79 isolates that were considered phenotypically resistant to tiamulin (MIC $\geq 8 \mu \mathrm{g} / \mathrm{ml}$ ), and 8 of these $l s a E$-positive isolates also contained the $a a d E$ or ant(6)-Ia gene conferring resistance to streptomycin (Tables 3, 5).

Some Lactobacillus strains simultaneously contained genes responsible for resistance to different antibiotics (Table 5).

None of the Lactobacillus isolates tested contained the tet $K$, tet $O$, tet $Q$, ermA, ermT, mefA/E, msrA/B, msrC,

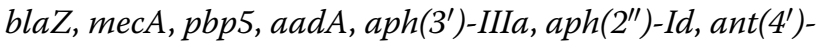
$I a, a a c\left(6^{\prime}\right)-I i, c f r, l s a C, v g a A, v g a A v$, mdeA, norA or mepA genes.

\section{Nitrocefin test}

The result of the nitrocefin test, which is considered a highly sensitive method for detection of the bacterial $\beta$-lactamase enzyme [19], was negative for all ampicillinresistant Lactobacillus isolates tested.

\section{Distribution of resistant isolates on farms}

In this work, we observed considerable variation in the percentage of resistant isolates among lactobacilli collected from individual farms. The range of ampicillin resistance was $9-62.5 \%$, tetracyclines $14-100 \%$, lincomycin $8-100 \%$, macrolides $0-92 \%$, streptomycin $0-54 \%$, gentamicin $0-23.5 \%$, chloramphenicol $0-53 \%$, tiamulin $75-100 \%$ and enrofloxacin $25-82 \%$ (Table 6).

All isolates from farm VII were sensitive to macrolides, and isolates from farms IV and VII-to chloramphenicol. No aminoglycoside resistance was observed on farms IV and V. Lactobacilli from farm VIII were characterized by a low percentage of isolates resistant to lincomycin (8\%).

The lowest percentage of multiresistant isolates (3157\%) and tetracycline resistant strains (14-31\%) was recorded on two farms raising Green-legged Partridge hens. Among 20 Lactobacillus isolates derived from these farms, one strain of L. ingluviei (Ch9e) did not show resistance to any antibiotic and 7 isolates showed phenotypic resistance to only one antibiotic (tiamulin); none of these 8 isolates contained any resistance genes, except acrA.

\section{Discussion}

In this study we assayed 88 Lactobacillus isolates of chicken origin with regard to their susceptibility to 13 antibacterial agents. We found high prevalence of resistance to tiamulin (90\% resistant isolates), tetracyclines (74\%), and lincosamides (70\%), and moderately high frequency of resistance to enrofloxacin (48\%), macrolides (42\%), aminoglycosides (12.5-31\%), ampicillin (26\% resistant isolates) and chloramphenicol (23\%).

Tiamulin, doxycycline, chlortetracycline, oxytetracycline, erythromycin, tylosin, lincomycin and enrofloxacin are currently approved for treatment of poultry diseases in Poland, and in the past some of these antibiotics were commonly used as feed additives for chickens. The intensive use and misuse of antibiotics in animal husbandry are unquestionably the major forces contributing to the development of resistance in bacteria, both pathogenic and commensal [20].

In this work we have presented the first reliable data on the sensitivity of lactobacilli to tiamulin. According to the proposed criteria, most isolates $(90 \%)$ were resistant to tiamulin (MIC $\geq 8 \mu \mathrm{g} / \mathrm{ml}$ ) and the most commonly observed MIC value was $64-128 \mu \mathrm{g} / \mathrm{ml}$ (for $64 \%$ of isolates). For $L$. salivarius, $L$. agilis, $L$. reuteri and $L$. ingluviei, we observed bimodal distribution of MIC values, with the MIC of $9 \%$ isolates as low as $\leq 0.5 \mu \mathrm{g} / \mathrm{ml}$. MIC values for tiamulin determined by Karpetkov et al. [21] for 3 isolates of Lactobacillus (L. acidophilus, L. helveticus and L. bulgaricus) were in the range of $0.5-1 \mu \mathrm{g} /$ $\mathrm{ml}$, while the sensitivity of other Gram-positive bacteria to tiamulin is varied. Callens et al. [22] showed that the MIC for Streptococcus suis (332 isolates tested) from pigs ranged from 0.03 to $128 \mu \mathrm{g} / \mathrm{ml}$, and MIC $=4 \mu \mathrm{g} / \mathrm{ml}$ was established as an epidemiological cut-off value. Jones et al. [23] showed that MIC90 was $>32 \mu \mathrm{g} / \mathrm{ml}$ for enterococci (71 isolates tested), and $2 \mu \mathrm{g} / \mathrm{ml}$ for $S$. aureus (150 isolates).

The observed phenotypic resistance of lactobacilli to tiamulin may be due to mutation in the 23S rRNA or in the $\mathrm{rplC}$ genes encoding ribosomal proteins. The presence of multidrug efflux pumps ( $v g a$ and $l s a$ ) is also possible [24]. None of the isolates contained the cfr gene coding for RNA methyltransferase or the vgaA, vgaAv and $l s a C$ genes encoding $\mathrm{ABC}$ transporters that confer combined resistance to pleuromutilins, lincosamides and streptogramin A antibiotics $\left(\mathrm{PLS}_{\mathrm{A}}\right)$ in Gram-positive bacteria [24]. However, in 10 isolates we detected the $l s a E$ gene, which has previously been identified in staphylococci, enterococci (Europe, Asia) and Streptococcus agalactiae (South America) [25]. Eight lasE-positive isolates simultaneously contained the aadE or ant(6)-Ia gene conferring resistance to streptomycin. This observation is in line with findings by $\mathrm{Si}$ et al. [25], who demonstrated the presence of the $l s a E$ gene within plasmid or chromosomal clusters comprising several resistance genes, including $a a d E$. 
Table 6 Percentage of resistant lactobacilli isolated from individual chicken farms

\begin{tabular}{|c|c|c|c|c|c|c|c|c|}
\hline \multirow{2}{*}{$\begin{array}{l}\text { Farm } \\
\text { Age of birds/no. of } \\
\text { Lactobacillus isolates }\end{array}$} & \multicolumn{6}{|c|}{ Broiler chickens } & \multicolumn{2}{|c|}{ Green-legged Partridge hens } \\
\hline & $\begin{array}{l}\text { I } \\
45 \text { days/ } \\
11(\%)\end{array}$ & $\begin{array}{l}\text { II } \\
49 \text { days/ } \\
13(\%)\end{array}$ & $\begin{array}{l}\text { III } \\
17 \text { days/ } \\
17(\%)\end{array}$ & $\begin{array}{l}\text { IV } \\
42 \text { days/ } \\
7(\%)\end{array}$ & $\begin{array}{l}\mathrm{V} \\
40 \text { days/ } \\
8(\%)\end{array}$ & $\begin{array}{l}\text { VI } \\
48 \text { days/ } \\
12(\%)\end{array}$ & $\begin{array}{l}\text { VII } \\
2 \text { days/ } \\
7(\%)\end{array}$ & $\begin{array}{l}\text { VIII } \\
49 \text { days/ } \\
13(\%)\end{array}$ \\
\hline Ampicillin & 9 & 15 & 29 & 43 & 62.5 & 25 & 28.5 & 15 \\
\hline Tetracyclines & 100 & 92 & 94 & 86 & 100 & 58 & 14 & 31 \\
\hline Lincomycin & 91 & 100 & 100 & 86 & 62.5 & 50 & 57 & 8 \\
\hline Macrolides & 54.5 & 92 & 70.5 & 43 & 25 & 8 & 0 & 8 \\
\hline Streptomycin & 45 & 54 & 29 & 0 & 0 & 50 & 28.5 & 15 \\
\hline Gentamicin & 9 & 23 & 23.5 & 0 & 0 & 17 & 14 & 0 \\
\hline Chloramphenicol & 9 & 31 & 53 & 0 & 12.5 & 25 & 0 & 15 \\
\hline Tiamulin & 82 & 92 & 88 & 100 & 75 & 100 & 86 & 92 \\
\hline Enrofloxacin & 27 & 61.5 & 82 & 57 & 25 & 42 & 28.5 & 31 \\
\hline Isolates without any resistance & 0 & 0 & 0 & 0 & 12.5 & 0 & 0 & 8 \\
\hline Resistance to one drug only & 0 & 0 & 0 & 0 & 0 & 0 & 43 & 31 \\
\hline Multidrug resistant isolates & 100 & 100 & 100 & 100 & 75 & 67 & 57 & 31 \\
\hline
\end{tabular}

High prevalence of tetracycline resistance $(74 \%$ of isolates) in the lactobacilli tested is in line with observations by Cauwerts et al. [3], who found that over $78 \%$ of lactobacilli isolated from Belgian broiler farms were resistant to tetracycline, with a particularly high rate of resistance observed among strains of $L$. reuteri, L. gallinarum, $L$. crispatus and L. salivarius. Also, Vieira De Souza et al. [26] reported a high incidence of tetracycline resistance (MIC $\geq 128 \mu \mathrm{g} / \mathrm{ml}$ ) among lactobacilli isolated from the GIT of free-range broiler chickens when resistance was determined by the microplate method using MRS broth. A lower incidence of resistance to tetracyclines (28\%) and macrolides (29\%) in faecal chicken lactobacilli was noted by Kmet and Piatnicova [27].

Acquired tetracycline resistance in bacteria is determined mainly by tet genes, which code for energydependent efflux proteins (e.g., tet $K$ and tetL) or ribosomal protection proteins (e.g., tet $M$, tet $O$, tet $Q$ or tet $W)[28,29]$. We showed the presence of tet $L$, tet $M$ and tet $W$ in the Lactobacillus isolates with phenotypic tetracycline-resistance. The occurrence of these genes, as well as $t e t K$ and $t e t Z$, in chicken lactobacilli (76\% of strains tested) was also observed by Cauwerts et al. [3]. However, in contrast to our results, these authors more frequently detected tet $L$ and tet $M$ than tet $W$. In a study by Chang et al. [30], 100\% of Lactobacillus strains isolated from swine intestines (in Taiwan) were resistant to tetracyclines; among 5 tet genes detected the most predominant was tetW (in $82 \%$ strains), followed by tetM (22.5\%), $L$ (14.4\%), $K(8.1 \%)$ and $Q(0.9 \%)$. The tet $W$ and tet $M$ genes have also been found in Lactobacillus strains derived from humans, probiotics and food products Klare et al. [31]. Our finding that the tet $W$ gene is characteristic for
L. crispatus, $L$. johnsonii and $L$. reuteri is consistent with the observations of other authors [3,32,33].

High rates of resistance to macrolides and lincosamides among chicken lactobacilli have previously been reported by Cauwerts et al. [4], who demonstrated that $78 \%$ of Lactobacillus strains (belonging to 5 species) from Belgian broiler farms displayed resistance to erythromycin and tylosin (MIC $\geq 16 \mu \mathrm{g} / \mathrm{ml}$ ) and $87 \%$ were resistant to lincomycin (MIC $\geq 64 \mu \mathrm{g} / \mathrm{ml}$ ). Chin et al. [34] found that $58 \%$ of lactobacilli isolated from the GIT of chickens exhibited a high degree of resistance to erythromycin (MIC $\geq 200 \mu \mathrm{g} / \mathrm{ml}$ ). A clear bimodal distribution of MICs for erythromycin and tylosin, indicative of acquired resistance, has also been reported by other authors in MLS-resistant lactobacilli derived from various sources $[4,12,33,35]$.

We have shown that the vast majority of Lactobacillus strains characterized by phenotypic resistance to macrolides and/or lincosamides contained resistance-related genes. PCR detection of methylase genes (erm), efflux genes ( $m e f$ and $m s r$ ) and the lincosamide $O$-nucleotidyltransferase gene $(\ln u A)$ confirmed a high incidence of $\operatorname{ermB}$ (in $39 \%$ of isolates) and $\ln u A(39 \%)$ in chicken lactobacilli, while ermC occurred less frequently (12\%). Our results are consistent with those of Cauwerts et al. [4], who found that carriage of the ermB gene always concurred with phenotypic resistance to macrolides and lincosamides in chicken lactobacilli. The same authors reported the occasional occurrence of the $\ln u A$, mefA and $\operatorname{erm} C$ genes. The ermB gene is also widespread in other poultry-derived LAB [36, 37]. Four of $11 \mathrm{ermC}$ positive isolates were susceptible to macrolides and at the same time displayed low resistance to lincomycin (MIC 
$16-64 \mu \mathrm{g} / \mathrm{ml})$. Our results are consistent with those of Cauwerts et al. [4], who showed that chicken Lactobacillus strains may carry the ermC gene without exhibiting phenotypic macrolide or lincosamide (MIC $\geq 64 \mu \mathrm{g} / \mathrm{ml}$ ) resistance. Note, however, that according to the cut-offs adopted by Cauwerts et al. [4], three of our strains carrying the ermC gene would be considered susceptible to both macrolides and lincosamides.

In this work, the $\ln u A$ gene encoding a transferase inducing inactivation of lincosamides was detected mainly in L. reuteri and L. ingluviei strains. The presence of $\ln u A$ in $L$. reuteri has previously been reported by Cauwerts et al. [4] (in chicken lactobacilli) and by Kastner et al. [32] (in the probiotic strain L. reuteri ATCC 55730).

Resistance to tetracyclines and macrolides and the tet and erm genes also occurs among Lactobacillus and Lactococcus strains isolated from various food sources, including poultry meat products $[38,39]$.

The incidence of ampicillin resistance (26\% isolates) recorded in this study is higher than that observed by other researchers working on poultry LAB over the past 15 years. Kmet and Piatnicova [27] showed that 100\% of Lactobacillus strains from cloacal swabs of broiler chickens raised on farms in Slovakia were susceptible to penicillin and ampicillin. High sensitivity of LAB isolated from Malaysian broiler chickens to $\beta$-lactams (penicillin, ampicillin and amoxicillin) has also been reported by Shazali et al. [40], and Lonkar et al. [41] noted only sporadic $\beta$-lactam resistance among poultry lactobacilli $(\leq 3.5 \%)$. Low ampicillin MICs (MIC $\leq 4 \mu \mathrm{g} / \mathrm{ml}$ ) have also been demonstrated for goose-derived lactobacilli [11]. We were unable to explain the resistance mechanism of Lactobacillus isolates against ampicillin, but we ruled out the involvement of $\beta$-lactamases. This is consistent with other studies demonstrating the absence of the blaZ gene in lactobacilli despite their phenotypic resistance to $\beta$-lactam antibiotics $[12,18]$.

In our study, $23 \%$ of isolates showed resistance to chloramphenicol, but for most of them the MICs were $8 \mu \mathrm{g} /$ $\mathrm{ml}$, while the established cut-off value is $4 \mu \mathrm{g} / \mathrm{ml}$. A high MIC value, $64 \mu \mathrm{g} / \mathrm{ml}$, was recorded for only one isolate. The cat gene encoding chloramphenicol acetyltransferase was detected in $37.5 \%$ of isolates, both phenotypically resistant and susceptible. A similar range of MIC values for chloramphenicol, i.e. $1-8 \mu \mathrm{g} / \mathrm{ml}$ for most lactobacilli tested, was observed by Mayrhofer et al. [42] and by Danielsen and Wind [43], while high MIC values $\geq 32 \mu \mathrm{g} /$ $\mathrm{ml}$ have been noted only occasionally $[12,43]$. Hummel et al. [18] demonstrated that the cat gene can be present in chloramphenicol-susceptible lactobacillus isolates, and furthermore that the cat gene in these strains was not expressed (RNA level) in either inducing or non-inducing conditions. The authors speculated that a mutation in the regulatory region may be responsible for the inhibition of cat expression in phenotypically susceptible isolates.

The frequency of resistance to aminoglycoside antibiotics among the Lactobacillus isolates was in a range of $12.5-31 \%$, with $L$. salivarius dominant among resistant isolates. High MIC values, i.e. $\geq 128 \mu \mathrm{g} / \mathrm{ml}$ for streptomycin, gentamicin and neomycin, were reported for 18 , 7 and $1 \%$ of isolates, respectively. Similarly, high-level resistance (MIC $\geq 128 \mu \mathrm{g} / \mathrm{ml}$ ) to streptomycin and gentamicin were reported by Danielsen and Wind [43] in 61 and 3\%, respectively, of Lactobacillus isolates of different species. Greater susceptibility of lactobacilli to aminoglycosides was observed by Korhonen [44] in bovine isolates, with MIC ranges of $0.25-8 \mu \mathrm{g} / \mathrm{ml}$ for gentamicin and $0.25-32 \mu \mathrm{g} / \mathrm{ml}$ for neomycin, while in the case of streptomycin an MIC of $2-32 \mu \mathrm{g} / \mathrm{ml}$ was recorded for $98 \%$ of isolates and MIC $=128 \mu \mathrm{g} / \mathrm{ml}$ for only one $L$. salivarius strain.

We were not able to establish the resistance status of all phenotypically resistant isolates, but in some of them we detected genes encoding aminoglycoside-modifying enzymes. Enzymatic modification is the most common type of aminoglycoside resistance, and the modifying enzymes are divided into three groups: $\mathrm{N}$-acetyltransferases (AAC), O-adenyltransferases (ANT, e.g., the ANT(6) group encoded by ant(6)-Ia, ant(6) and aadE and the ANT $\left(3^{\prime \prime}\right)$ group encoded by aadA genes) and O-phosphoryltransferases (APH; encoded by aph genes, including $a p h\left(3^{\prime}\right)-I I I a$ and $a p h(6)-I a$, also known as $\operatorname{str} A$ [17].

Among the lactobacilli tested we identified ant(6)-

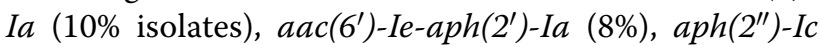
(6\%) and $\operatorname{addE}(4.5 \%)$. Our results are largely consistent with literature data, which indicate that the most frequently detected aminoglycoside resistance genes in $\mathrm{LAB}$ are $a a c\left(6^{\prime}\right)-I e-a p h\left(2^{\prime \prime}\right)-I a$, ant(6)-Ia, ant (6), $a a c\left(6^{\prime}\right)$ Ii, aph(2')-Ic, aph(3')-IIIa, aadA and aadE [15, 45-48]. Tenorio et al. [49] demonstrated the presence of the bifunctional gene $a a c\left(6^{\prime}\right)-I e-a p h\left(2^{\prime \prime}\right)-I a$ in 7 of 9 phenotypically gentamicin-resistant (MIC of $\geq 64 \mu \mathrm{g} / \mathrm{ml}$ ) strains, including $L$. salivarius, from pigs and pets. Jaimee and Halami [50] and Rojo-Bezares et al. [48] noted

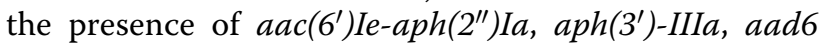
and ant(6) among $L$. plantarum isolates derived from meat products or wine. The presence of $a a d E$, aph $\left(3^{\prime}\right)$ III a and aadA in 3 of 16 tested isolates of L. casei, L. paracasei and $L$. plantarum was reported by Ouoba et al. [51]. Similarly to our results, the presence of aminoglycoside resistance genes in phenotypically sensitive lactobacillus strains has been observed by Shao et al. [47], who detected ant(6), aadE and aadA (conferring resistance to streptomycin) in $3 \mathrm{~L}$. casei isolates (streptomycin MIC $16-32 \mu \mathrm{g} / \mathrm{ml}$ ) and in $5 \mathrm{~L}$. plantarum isolates (MIC 
16-512 $\mu \mathrm{g} / \mathrm{ml}$ ) from food sources. The authors stated that these eight isolates were phenotypically resistant to streptomycin, but according to breakpoints established by the EFSA (2012), L. casei strains are regarded as resistant if streptomycin MIC $\geq 128 \mu \mathrm{g} / \mathrm{ml}$, while there are no established breakpoints for L. plantarum. Another imprecision in the publication by Shao et al. [47] is the size of the PCR product for the aadE genethe amplicon size obtained using the described primers is $1100 \mathrm{bp}$, not $565 \mathrm{bp}$.

In this work we observed the co-occurrence of ant(6)Ia and $a a d E$ genes in a few L. salivarius isolates. Both genes determine resistance to streptomycin, belong to the ANT(6) subclass [17] and some authors use their names interchangeably $[52,53]$. Thus it is very likely that ant(6)-Ia and $a a d E$ identified in this study are the same gene detected with different primers. Sequencing of ant(6)-Ia and aadE amplicons revealed 97-99\% homology to the sequence of $a a d E$ gene located on the $l s a(E)$ carrying multidrug resistance cluster of Enterococcus faecalis (GenBank Accession No. KX156279.1) and to aadE gene of Staphylococcus aureus (GenBank Accession No. JQ861959.1) (data not shown).

The range of MICs observed in this work for fluoroquinolones, i.e. $2-256 \mu \mathrm{g} / \mathrm{ml}$ for enrofloxacin and 8-512 $\mu \mathrm{g} /$ $\mathrm{ml}$ for flumequine, was similar to the range of MICs previously recorded for goose lactobacilli [11]. However, according to the proposed cut-off value, the rate of enrofloxacin-resistant strains ( $\mathrm{MIC} \geq 64 \mu \mathrm{g} / \mathrm{ml}$ ) was higher among chicken isolates (48\%) than in isolates derived from geese (23\%). Other authors have reported greater susceptibility of LAB to enrofloxacin. The MIC range noted by Ishihara et al. [54] for lactobacilli isolated from dairy products was $1-8 \mu \mathrm{g} / \mathrm{ml}$, and in the case of bovine lactobacilli $\mathrm{MIC} \geq 64 \mu \mathrm{g} / \mathrm{ml}$ was noted for only $3 \%$ of isolates [44]. The presence of low MIC values for enrofloxacin, i.e. $0.5-2.0 \mu \mathrm{g} / \mathrm{ml}$, was also observed by Marrow et al. [55] for enterococci isolates from free-living and captive raptors.

Among the genes coding efflux pumps we detected only acrA, which was present in all Lactobacillus isolates. High prevalence of $a c r A$ among LAB isolated from fermented olives has previously been noted by Casado Muñoz et al. [56]. These authors also observed a high frequency of mepA and mdeA and lower frequency of norA. According to some reports $[57,58]$, the overexpression of all these genes in Enterobacteriaceae is correlated with fluoroquinolone and multidrug resistance. In this work we did not evaluate the expression of the acrA gene, but its presence in all isolates indicates its role in cell physiology rather than its involvement in antibiotic resistance.

Resistance genes are commonly found on mobile genetic elements, such as plasmids, transposons or integrons, contributing to their widespread distribution among bacteria. Some authors have shown that LAB, including lactobacilli, may contain tetL-, tetM-, tet $W$-, ermB-, ermC, lnuA, aac(6')-Ie-aph(2")-Ia-, aadE-, ant(6)$I a$ or $l s a E$-carrying plasmids or transposons [33, 59-63]. It has also been shown that the resistance genes $\operatorname{erm} B$ and tet $M$ can be transferred between different Lactobacillus species, as well from lactobacilli to other $\mathrm{LAB}$ bacteria, including potentially pathogenic strains of $E$. faecalis $[26,60]$.

\section{Conclusions}

Our work presents a comprehensive study on the antimicrobial nature of chicken lactobacilli, and includes the first report of the susceptibility of bacteria of the genus Lactobacillus to tiamulin. This is also the first record demonstrating the presence of the $l s a E$ gene in lactobacilli, as well as some other resistance genes that have not previously been detected in the Lactobacillus species tested in this work.

We have shown a high frequency of resistance $(\geq 70 \%$ resistant isolates) to tiamulin, tetracyclines and lincosamides among Lactobacillus isolates of chicken origin, and the prevalence of resistance to the other drugs tested ranged from 12.5 to $48 \%$.

A major contributor to the development of antibiotic resistance in commensal microflora is their widespread use in poultry farming. Therefore it is essential to advise veterinarians and farmers to limit the use of antibiotics in chickens and to draw their attention to alternative methods of prevention and treatment.

Due to the prevalence of molecular determinants of drug resistance, chicken intestinal lactobacilli can be considered a reservoir of resistance genes. Since these genetic determinants are generally associated with mobile elements of the bacterial genome, they may be transferred to potentially pathogenic bacteria, including zoonotic agents. Thus their presence in lactobacilli may contribute to the development of opportunistic infections in poultry and may constitute a potential public health hazard.

The data derived from this study can be used as a basis for reviewing present microbiological breakpoints for categorization of susceptible and resistant strains within the genus Lactobacillus.

\section{Authors' contributions}

MD designed the study and interpreted the data, supervised all experiments and drafted the manuscript. MD, DSP and RUC performed laboratory work. AW revised the manuscript critically for important intelectual content. All authors read and approved the final manuscript.

\section{Acknowledgements}

Not applicable.

\section{Competing interests}

The authors declare that they have no competing interests. 


\section{Availability of data and materials}

The IsaE gene sequences supporting the results were deposited in the NCBI Genbank database under the Accession Number KY924692.

\section{Consent for publication}

Not applicable.

\section{Ethics approval and consent to participate}

The faecal samples and cloacal from the birds were collected by a veterinarian as part of his work. According to Polish law (the act on experiments on animals of 21 January 2005), permission from the ethics commission is not required for this type of sample collection.

\section{Funding}

All stages of research and writing of the manuscript were financed entirely from the budget of the University of Life Sciences in Lublin, Poland.

\section{Publisher's Note}

Springer Nature remains neutral with regard to jurisdictional claims in published maps and institutional affiliations.

Received: 9 August 2017 Accepted: 5 September 2017 Published online: 19 September 2017

\section{References}

1. Lebeer S, Vanderleyden J, De Keersmaecker SC. Genes and molecules of lactobacilli supporting probiotic action. Microbiol Mol Biol Rev. 2008;72:728-64.

2. Schjørring S, Krogfelt KA. Assessment of bacterial antibiotic resistance transfer in the gut. Int J Microbiol. 2011;2011:1-10.

3. Cauwerts K, Pasmans F, Devriese LA, Haesebrouck F, Decostere A. Cloacal Lactobacillus isolates from broilers often display resistance toward tetracycline antibiotics. Microb Drug Resist. 2006;12:284-8.

4. Cauwerts K, Pasmans F, Devriese LA, Martel A, Haesebrouck F, Decostere A. Cloacal Lactobacillus isolates from broilers show high prevalence of resistance towards macrolide and lincosamide antibiotics. Avian Pathol. 2006;35:160-4.

5. Saif YM. Aly M. Fadly AM, John R. Glisson JR, Larry R. McDougald LR, Nolan LK, Swayne DE, editors. Diseases of poultry. 12th edition. lowa State, USA Blackwell Publishing: 2008. p. 752, 771, 821, 875, 896, 934

6. McMullin P. Medicines and Medication. In: McMullin P, Janet Bradbury J, Alexander D, editors. Pattison M. 6th edition ed. Philadelphia: Poultry Diseases. Saunders Ltd.; 2007. p. 82-93.

7. Lambert T. Antibiotics that affect the ribosome. Rev Sci Tech. 2012;31:57-64.

8. Tenover FC. Mechanisms of antimicrobial resistance in bacteria. Am J Infect Control. 2006;34:S3-10 (discussion S64-73).

9. EFSA Panel on Additives and Products or Substances used in Animal Feed (FEEDAP). Guidance on the assessment of bacterial susceptibility to antimicrobials of human and veterinary importance. EFSA J. 2012;10:2740.

10. Dec M, Puchalski A, Urban-Chmiel R, Wernicki A. 16S-ARDRA and MALDITOF mass spectrometry as tools for identification of Lactobacillus bacteria isolated from poultry. BMC Microbiol. 2016;16:105.

11. Dec M, Wernicki A, Puchalski A, Urban-Chmiel R. Antibiotic susceptibility of Lactobacillus strains isolated from domestic geese. Br Poult Sci. 2015;56:416-24

12. Mayrhofer S, Van Hoek AH, Mair C, Huys G, Aarts HJ, Kneifel W, Domig KJ. Antibiotic susceptibility of members of the Lactobacillus acidophilus group using broth microdilution and molecular identification of their resistance determinants. Int J Food Microbiol. 2010;144:81-7.

13. ISO 10932/IDF 223 - Interantional Organization of Standarization/International Dairy Federation. Milk and milk products. Determination of the minimal inhibitory concentration (MIC) of antibiotics applicable to bifidobacteria and non-enterococcal lactic acid bacteria (LAB). 1st edition. ISO and IDF 2010, Geneva, Switzerland.
14. Malhotra-Kumar S, Lammens C, Piessens J, Goossens H. Multiplex PCR for simultaneous detection of macrolide and tetracycline resistance determinants in streptococci. Antimicrob Agents Chemother. 2005;49:4798-800.

15. Vakulenko SB, Donabedian SM, Voskresenskiy AM, Zervos MJ, Lerner SA, Chow JW. Multiplex PCR for detection of aminoglycoside resistance genes in enterococci. Antimicrob Agents Chemother. 2003;47:1423-6.

16. Van TT, Chin J, Chapman T, Tran LT, Coloe PJ. Safety of raw meat and shellfish in Vietnam: an analysis of Escherichia coli isolations for antibiotic resistance and virulence genes. Int J Food Microbiol. 2008;124:217-23.

17. Ramirez MS, Tolmasky ME. Aminoglycoside modifying enzymes. Drug Resist Updat. 2010;13:151-71.

18. Hummel AS, Hertel C, Holzapfel WH, Franz CM. Antibiotic resistances of starter and probiotic strains of lactic acid bacteria. Appl Environ Microbiol. 2007;73:730-9

19. Bidya S, Suman RS. Comparative study of three $\beta$ lactamase test methods in Staphylococcus aureus isolated from two nepalese hospitals. OJCD. 2014;4:47-52.

20. McEwen SA, Fedorka-Cray PJ. Antimicrobial use and resistance in animals. Clin Infect Dis. 2002;1 (34 Suppl 3):S93-106

21. Karapetkov N, Georgieva R, Rumyan N, Karaivanova E. Antibiotic susceptibility of different lactic acid bacteria strains. Benef Microbes. 2011;2:335-9.

22. Callens BF, Haesebrouck F, Maes D, Butaye P, Dewulf J, Boyen F. Clinical resistance and decreased susceptibility in Streptococcus suis isolates from clinically healthy fattening pigs. Microb Drug Resist. 2013;19:146-51.

23. Jones RN, Pfaller MA, Rhomberg PR, Walter DH. Tiamulin activity against fastidious and nonfastidious veterinary and human bacterial isolates: initialdevelopment of in vitro susceptibility test methods. J Clin Microbiol. 2002:40:461-5.

24. van Duijkeren E, Greko C, Pringle M, Baptiste KE, Catry B, Jukes H, Moreno MA, Pomba MC, Pyörälä S, Rantala M, Ružauskas M, Sanders P, Teale C, Threlfall EJ, Torren-Edo J, Törneke K. Pleuromutilins: use in foodproducing animals in the European Union, development of resistance and impact on human and animal health. J Antimicrob Chemother. 2014;69:2022-31.

25. Si H, Zhang WJ, Chu S, Wang XM, Dai L, Hua X, Dong Z, Schwarz S, Liu S. Novel plasmid-borne multidrug resistance gene cluster including $/ \mathrm{sa}(\mathrm{E})$ from a linezolid-resistant Enterococcus faecium isolate of swine origin. Antimicrob Agents Chemother. 2015;59:7113-6.

26. De Vieira Souza F, Roque R, Silva Moreira JL, Resende De Souza M, Nicoli JR, Neumann E, Cantini Nunes Á. Transfer of antibiotic resistance determinants between lactobacilli isolates from the gastrointestinal tract of chicken. Benef Microbes. 2012;3:137-44.

27. Kmet V, Piatnicová E. Antibiotic resistance in commensal intestinal microflora. Folia Microbiol. (Praha). 2010;55:332-5.

28. Chopra I, Roberts M. Tetracycline antibiotics: mode of action, applications, molecular biology, and epidemiology of bacterial resistance. Microbiol Mol Biol Rev. 2001;65:232-60.

29. Roberts MC. Update on macrolide-lincosamide-streptogramin, ketolide, and oxazolidinone resistance genes. FEMS Microbiol Lett. 2008:282:147-59

30. Chang YC, Tsai CY, Lin CF, Wang YC, Wang IK, Chung TC. Characterization of tetracycline resistance lactobacilli isolated from swine intestines at western area of Taiwan. Anaerobe. 2011;17:239-45.

31. Klare I, Konstabel C, Werner G, Huys G, Vankerckhoven V, Kahlmeter G, Hildebrandt B, Müller-Bertling S, Witte W, Goossens H. Antimicrobial susceptibilities of Lactobacillus, Pediococcus and Lactococcus human isolates and cultures intended for probiotic or nutritional use. J Antimicrob Chemother. 2007;59:900-12.

32. Kastner S, Perreten V, Bleuler H, Hugenschmidt G, Lacroix C, Meile $\mathrm{L}$. Antibiotic susceptibility patterns and resistance genes of starter cultures and probiotic bacteria used in food. Sys Appl Microbiol. 2006;29:145-55.

33. Egervärn $M$, Roos S, Lindmark H. Identification and characterization of antibiotic resistance genes in Lactobacillus reuteri and Lactobacillus plantarum. J App Microbiol. 2009;107:1658-68.

34. Chin SC, Abdullah N, Siang TW, Wan HY. Plasmid profiling and curing of Lactobacillus strains isolated from the gastrointestinal tract of chicken. J Microbiol. 2005;43:251-6. 
35. Delgado S, Flórez AB, Mayo B. Antibiotic susceptibility of Lactobacillus and Bifidobacterium species from the human gastrointestinal tract. Curr Microbiol. 2005;50:202-7

36. Aarestrup FM, Agers $\varnothing$ Y, Ahrens P, Østergaard Jørgensen JC, Madsen M, Jensen LB. Antimicrobial susceptibility and presence of resistance genes in staphylococci from poultry. Vet Microbiol. 2000;74:353-64.

37. Khan AA, Nawaz MS, Khan SA, Steele R. Detection and characterization of erythromycin-resistant methylase genes in gram-positive bacteria isolated from poultry litter. Appl Microbiol Biotechnol. 2002;59:377-81.

38. Aquilanti L, Garofalo C, Osimani A, Silvestri G, Vignaroli C, Clementi F. Isolation and molecular characterization of antibiotic-resistant lactic acid bacteria from poultry and swine meat products. J Food Prot. 2007;70:557-65.

39. Zonenschain D, Rebecchi A, Morelli L. Erythromycin- and tetracyclineresistant lactobacilli in Italian fermented dry sausages. J App Microbiol. 2009;107:1559-68.

40. Shazali N, Foo HL, Loh TC, Choe DW, Abdul Rahim R. Prevalence of antibiotic resistance in lactic acid bacteria isolated from the faeces of broiler chicken in Malaysia. Gut Pathog. 2014;6:1.

41. Lonkar P, Harne SD, Kalorey DR, Kurkure NV. Isolation, in vitro antibacterial activity, bacterial sensitivity and plasmid profile of lactobacilli. Asian-Aust J Anim Sci. 2005;18:1336-42.

42. Mayrhofer S, Zitz U, Birru FH, Gollan D, Gołoś AK, Kneifel W, Domig KJ. Comparison of the CLSI guideline and ISO/IDF standard for antimicrobial susceptibility testing of lactobacilli. Microb Drug Resist. 2014;20:591-603.

43. Danielsen M, Wind A. Susceptibility of Lactobacillus spp. to antimicrobial agents. Int J Food Microbiol. 2003;26:1-11.

44. Korhonen J. Antibiotic resistance of lactic acid bacteria dissertations in forestry and natural sciences. Publications of the University of Eastern Finland Dissertations in Forestry and Natural Sciences. Kuopio. 2010.

45. Kobayashi N, Alam M, Nishimoto Y, Urasawa S, Uehara N, Watanabe N. Distribution of aminoglycoside resistance genes in recent clinical isolates of Enterococcus faecalis, Enterococcus faecium and Enterococcus avium. Epidemiol Infect. 2001;126:197-204.

46. Jackson CR, Fedorka-Cray PJ, Barrett JB, Ladely SR. Genetic relatedness of high-level aminoglycoside-resistant enterococci isolated from poultry carcasses. Avian Dis. 2004;48:100-7.

47. Shao Y, Zhang W, Guo H, Pan L, Zhang H, Sun T. Comparative studies on antibiotic resistance in Lactobacillus casei and Lactobacillus plantarum. Food Control. 2015;50:250-8.

48. Rojo-Bezares B, Sáenz Y, Poeta P, Zarazaga M, Ruiz-Larrea F, Torres C. Assessment of antibiotic susceptibility within lactic acid bacteria strains isolated from wine. Int J Food Microbiol. 2006;111:234-40.

49. Tenorio C, Zarazaga M, Martinez C, Torres C. Bifunctional enzyme $6^{\prime}$ - $\mathrm{N}$-aminoglycoside cetyltransferase-2" $-\mathrm{O}$ aminoglycosidephosphotransferase in Lactobacillus and Pediococcus isolates of animal origin. J Clin Microbiol. 2001;39:824-5.

50. Jaimee G, Halami PM. High level aminoglycoside resistance in Enterococcus, Pediococcus and Lactobacillus species from farm animals and commercial meat products. Ann Microbiol. 2016:66:101-10.

51. Ouoba LI, Lei V, Jensen LB. Resistance of potential probiotic lactic acid bacteria and bifidobacteria of African and European origin to antimicrobials: determination and transferability of the resistance genes to other bacteria. Int J Food Microbiol. 2008;121:217-24.

52. Aarestrup FM, Jensen LB. Trends in antimicrobial susceptibility in relation to antimicrobial usage and presence of resistance genes in Staphylococcus hyicus isolated from exudative epidermitis in pigs. Vet Microbiol. 2002;89:83-94.

53. Jeric PE, Azpiroz A, Lopardo H, Centrón D. Survey of molecular determinants in Gram-positive cocci isolated from hospital settings in Argentina. J Infect Dev Ctries. 2007;1:275-83.

54. Ishihara K, Nakajima K, Kishimoto S, Atarashi F, Muramatsu Y, Hotta A, Ishii S, Takeda Y, Kikuchi M, Tamura Y. Distribution of antimicrobial-resistant lactic acid bacteria in natural cheese in Japan. Microbiol Immunol. 2013;57:684-91.

55. Marrow J, Whittington JK, Mitchell M, Hoyer LL. Maddox Prevalence and antibiotic-resistance characteristics of Enterococcus spp. Isolated from free-living and captive raptors in Central Illinois. J Wildl Dis. 2009;45:302-13.

56. Casado Muñoz Mdel C, Benomar N, Lerma LL, Gálvez A, Abriouel H. Antibiotic resistance of Lactobacillus pentosus and Leuconostoc pseudomesenteroides isolated from naturally-fermented Aloreña table olives throughout fermentation process. Int J Food Microbiol. 2014;172:110-8.
57. Andersen JL, He GX, Kakarla P, KC R, Kumar S, Lakra WS, Mukherjee MM, Ranaweera I, Shrestha U, Tran T, Varela MF. Multidrug efflux pumps from Enterobacteriaceae, Vibrio cholerae and Staphylococcus aureus bacterial food pathogens. Int J Environ Res Public Health. 2015;12:1487-547.

58. Swick MC, Morgan-Linnell SK, Carlson KM, Zechiedrich L. Expression of multidrug efflux pump genes acrAB-to/C, $m d f A$, and norE in Escherichia coli clinical isolates as a function of fluoroquinolone and multidrug resistance. Antimicrob Agents Chemother. 2011;55:921-4.

59. Schwarz FV, Perreten $V$, Teuber M. Sequence of the 50-kb conjugative multiresistance plasmid pRE25 from Enterococcus faecalis RE25. Plasmid. 2001;46:170-87.

60. Gevers D, Huys G, Swings J. In vitro conjugal transfer of tetracycline resistance from Lactobacillus isolates to other Gram-positive bacteria. FEMS Microbiol Lett. 2003;225:125-30.

61. Ammor MS, Gueimonde M, Danielsen M, Zagorec M, Van Hoek AH, De Los Reyes-Gavilán CG, Mayo B, Margolles A. Two different tetracycline resistance mechanisms, plasmid-carried tet $(\mathrm{L})$ and chromosomally located transposon-associated tet(M), coexist in Lactobacillus sakei Rits 9. Appl Environ Microbiol. 2008;2008(74):394-401.

62. Feld L, Bielak E, Hammer K, Wilcks A. Characterization of a small erythromycin resistance plasmid pLFE1 from the food-isolate Lactobacillus plantarum M345. Plasmid. 2009;61:159-70.

63. Behnood A, Farajnia S, Moaddab SR, Ahdi-Khosroshahi S, Katayounzadeh A. Prevalence of aac $\left(6^{\prime}\right)$-le-aph(2")-la resistance gene and its linkage to Tn5281 in Enterococcus faecalis and Enterococcus faecium isolates from Tabriz hospitals. Iran J Microbiol. 2013;5:203-8.

64. Ng LK, Martin I, Alfa M, Mulvey M. Multiplex PCR for the detection of tetracycline resistant genes. Mol Cell Probes. 2001;15:209-15.

65. Masco L, Van Hoorde K, De Brandt E, Swings J, Huys G. Antimicrobial susceptibility of Bifidobacterium strains from humans, animals and probiotic products. J Antimicrob Chemother. 2006;58:85-94.

66. Toomey N, Bolton D, Fanning S. Characterisation and transferability of antibiotic resistance genes from lactic acid bacteria isolated from Irish pork and beef abattoirs. Res Microbiol. 2010;161:127-35.

67. Werner G, Hildebrandt B, Witte W. The newly described msrC gene is not equally distributed among all isolates of Enterococcus faecium. Antimicrob Agents Chemother. 2001:45:3672-3.

68. Kehrenberg C, Schwarz S. Distribution of florfenicol resistance genes fexA and cfr among chloramphenicol-resistant Staphylococcus isolates. Antimicrob Agents Chemother. 2006;50:1156-63.

69. Li XS, Dong WC, Wang XM, Hu GZ, Wang YB, Cai BY, Wu CM, Wang Y, Du $X D$. Presence and genetic environment of pleuromutilin-lincosamidestreptogramin A resistance gene $/ s a(E)$ in enterococci of human and swine origin. J Antimicrob Chemother. 2014;69:1424-6.

70. Li J, Li B, Wendlandt S, Schwarz S, Wang Y, Wu C, Ma Z, Shen J. Identification of a novel $v g a(E)$ gene variant that confers resistance to pleuromutilins, lincosamides and streptogramin A antibiotics in staphylococci of porcine origin. J Antimicrob Chemother. 2014;69:919-23.

71. Haroche J, Morvan A, Davi M, Allignet J, Bimet F, El Solh N. Clonal diversity among streptogramin A-resistant Staphylococcus aureus isolates collected in Frenchhospitals. J Clin Microbiol. 2003;41:586-91.

72. Garofalo C, Vignaroli C, Zandri G, Aquilanti L, Bordoni D, Osimani A, Clementi F, Biavasco F. Direct detection of antibiotic resistance genes in specimens of chicken and pork meat. Int J Food Microbiol. 2007;113:75-83.

73. Lee JH. Methicillin (Oxacillin)-resistant Staphylococcus aureus strains isolated from major food animals and their potential transmission to humans. Appl Environ Microbiol. 2003;69:6489-94.

74. Obeng AS, Rickard H, Ndi O, Sexton M, Barton M. Comparison of antimicrobial resistance patterns in enterococci from intensive and free range chickens in Australia. Avian Pathol. 2013:42:45-54.

75. Patel D, Kosmidis C, Seo SM, Kaatz GW. Ethidium bromide MIC screening for enhanced efflux pump gene expression or efflux activity in Staphylococcus aureus. Antimicrob Agents Chemother. 2010;54:5070-3. 